\title{
The TRAX, DISC1, and GSK3 complex in mental disorders and therapeutic interventions
}

\author{
Yu-Ting Weng ${ }^{1,2}$, Ting Chien ${ }^{1}$, I-I Kuan ${ }^{1}$ and Yijuang Chern ${ }^{1,2^{*}}$
}

\begin{abstract}
Psychiatric disorders (such as bipolar disorder, depression, and schizophrenia) affect the lives of millions of individuals worldwide. Despite the tremendous efforts devoted to various types of psychiatric studies and rapidly accumulating genetic information, the molecular mechanisms underlying psychiatric disorder development remain elusive. Among the genes that have been implicated in schizophrenia and other mental disorders, disrupted in schizophrenia 1 (DISC1) and glycogen synthase kinase 3 (GSK3) have been intensively investigated. DISC1 binds directly to GSK3 and modulates many cellular functions by negatively inhibiting GSK3 activity. The human DISC1 gene is located on chromosome 1 and is highly associated with schizophrenia and other mental disorders. A recent study demonstrated that a neighboring gene of DISC1, translin-associated factor $X$ (TRAX), binds to the DISC1/GSK3 $\beta$ complex and at least partly mediates the actions of the DISC1/GSK3 $\beta$ complex. Previous studies also demonstrate that TRAX and most of its interacting proteins that have been identified so far are risk genes and/or markers of mental disorders. In the present review, we will focus on the emerging roles of TRAX and its interacting proteins (including DISC1 and GSK3 3 ) in psychiatric disorders and the potential implications for developing therapeutic interventions.
\end{abstract}

Keywords: TRAX, DISC1, GSK3 $\beta$, Mental disorders, DNA damage, DNA repair, Oxidative stress, $A_{2 A} R$, PKA

\section{Background}

Mental disorders (such as bipolar disorder, depression, and schizophrenia) have recently become great concerns because of the resultant heavy social and economic burdens on societies [1-3]. Rapidly progressing genetic technologies have provided many details regarding the genetic nature of mental disorders. Among the genes that have been revealed by genetic analyses of schizophrenia and other mental disorders, the function of disrupted in schizophrenia 1 (DISC1) has been intensively investigated. Biochemical investigations suggest that DISC1 is a scaffold protein that regulates various cellular functions (including cytoskeletal processes, intracellular transport, dendritic spine development activities, neuronal development, the cAMP-signaling pathway, and

\footnotetext{
* Correspondence: bmychern@ibms.sinica.edu.tw

'Institute of Biomedical Sciences, Academia Sinica, 128 Sec. 2, Academia Rd. Nankang, Taipei 115, Taiwan, Republic of China

${ }^{2}$ Program in Molecular Medicine, National Yang-Ming University and

Academia Sinica, No.155, Sec.2, Linong Street, Taipei 112, Taiwan, Republic of China
}

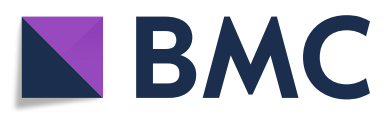

(๑) The Author(s). 2018 Open Access This article is distributed under the terms of the Creative Commons Attribution 4.0 International License (http://creativecommons.org/licenses/by/4.0/), which permits unrestricted use, distribution, and reproduction in any medium, provided you give appropriate credit to the original author(s) and the source, provide a link to the Creative Commons license, and indicate if changes were made. The Creative Commons Public Domain Dedication waiver (http://creativecommons.org/publicdomain/zero/1.0/) applies to the data made available in this article, unless otherwise stated.
DNA repair) by interacting with various proteins [4-12]. schizophrenia and possibly other mental diseases (Table 1).

Previous genetic studies have associated DISC1 and a neighboring gene (translin-associated factor X, TSNAX) with multiple mental disorders (e.g., schizophrenia, bipolar spectrum disorder, and major depressive disorder) [13-15] (Table 1). TRAX was initially identified as a binding partner of an RNA/DNA-binding protein (translin [16]). Further investigations revealed that similar to DISC1, TRAX regulates distinct cellular functions by selectively binding to designated partner(s). Moreover, the list of TRAX-interacting proteins overlaps with that of DISC1 (Table 2). Both TRAX and DISC1 are involved in facilitating DNA repair [5]. Chien et al. demonstrated that TRAX forms a complex with DISC1 and GSK3 $\beta$ in the cytoplasmic region of resting neurons. Upon stresses that cause oxidative DNA damage, inhibiting GSK3 $\beta$ causes the TRAX/DISC1/GSK3 $\beta$ complex to dissociate 
Table 1 Potential involvement of TRAX-interacting proteins in three psychiatric disorders

\begin{tabular}{|c|c|c|c|c|c|}
\hline Binding partner & Full name & Gene name & Schizophrenia & Autism & Panic attack \\
\hline$A_{2 A} R[5,132,134]$ & $\mathrm{A}_{2 \mathrm{~A}}$ adenosine receptor & ADORA2A & Drug target [164-166] & Risk gene (\#) & Risk gene [167] \\
\hline Akap9 [168] & A-kinase anchoring protein 9 & AKAP9 & Risk gene $[169,170]$ & $\begin{array}{l}\text { Risk gene } \\
(\#,[171-173])\end{array}$ & Risk gene [167] \\
\hline ATM [137] & Ataxia telangiectasia mutated & ATM & Risk gene $[139,174]$ & - & - \\
\hline \multirow[t]{2}{*}{ C1D [136] } & nuclear matrix protein $\mathrm{C} 1 \mathrm{D}$ & C1D & (1) Risk gene $\left(^{*}\right)$ & - & - \\
\hline & & & (2) Drug target [175] & & \\
\hline \multirow[t]{2}{*}{ DISC1 [5] } & Disrupted in schizophrenia 1 & DISC1 & (1) Risk gene $\left(^{*}\right)$ & Risk gene $[176,177]$ & Risk gene [167] \\
\hline & & & (2) Drug target $[116,178]$ & & \\
\hline \multirow[t]{2}{*}{ GSK3 $\beta[5]$} & Glycogen Synthase Kinase 3 Beta & GSK3B & (1) Risk gene $\left(^{*}\right)$ & Risk gene $[179,180]$ & Risk gene [181] \\
\hline & & & (2) Drug target [182] & & \\
\hline KIF2A $[134,183]$ & Kinesin Family Member 2A & KIF2A & Risk gene $(*)$ & - & - \\
\hline MEA2 [168] & Male-enhanced antigen 2 & MEA2 & - & - & - \\
\hline PLCß1 $[184,185]$ & Phospholipase C Beta 1 & PLCB1 & Risk gene $\left(^{*}\right.$, [185-187]) & Risk gene (\#, [188]) & - \\
\hline SUN1 [168] & SUN domain-containing protein 1 & SUN1 & - & - & - \\
\hline Translin $[126-128,130,189,190]$ & Translin & TSN & Risk gene [191, 192] & Risk gene (\#, [193]) & - \\
\hline TRAX-interacting protein-1 [22] & $\begin{array}{l}\text { Translin Associated Factor X } \\
\text { Interacting Protein } 1\end{array}$ & TSNAXIP1 & Risk gene [194] & - & - \\
\hline
\end{tabular}

The corresponding references are listed in parentheses. "-", no information. *, http://www.szdb.org/score.php. \#, https://gene.sfari.org/database/human-gene/

and release TRAX to facilitate ATM-mediated DNA repair [5]. Because the incomplete repair of oxidative DNA damage may contribute to the development of psychotic disorders $[1,17,18]$ and because TRAX and many of its interacting proteins (Table 1) are risk genes and/or markers of mental disorders, the present review focuses on the emerging role of TRAX/DISC1 interactome(s) in DNA repair as well as their potential implications in psychiatric disorders.

\section{DNA damage, oxidative stress, and mental health}

Reactive oxygen species (ROS) are usually generated through mitochondrial oxidative reactions [19]. Excessive ROS levels are a source of oxidative stress, which causes oxidative damage to DNA, proteins and lipids. ROS can attack the nitrogenous bases and sugar-phosphate backbone of DNA to cause single- and double-stranded DNA breaks that ultimately lead to genetic mutations and toxicity [20]. When cells are subjected to increased levels of ROS and reactive nitrogen species, multiple cellular impairments (e.g., oxidative DNA damage) occur [21]. Accumulating evidence suggests that elevated ROS levels and the resultant oxidative damage are major factors in human health and diseases [21-24]. Because the brain uses approximately $20 \%$ of the total oxygen in the body and generates significant amounts of free radicals, the brain is more susceptible to oxidative stress than other organs. Moreover, elevated ROS levels have been implicated in most neurological diseases (such as mental disorder and neurodegenerative diseases) [25-27]. Elevated levels of serum oxidative markers (such as 8-hydroxy-2'-deoxyguanosine, 8-OHdG) have also been reported in patients with trauma or diseases of the brain [28-31].

Ample evidence suggests that increased oxidative stress, which may cause oxidative DNA damage and mitochondrial dysfunction, is a common feature of mental disorders in the brain. Mitochondrial dysfunction is associated directly with elevated levels of oxidative stress and the progression of mental disorders [18, 19, 32]. For example, the nuclear gene expression levels of mitochondrial proteins, including electron transport chain (ETC) complexes I-V, are significantly decreased in the hippocampus and postmortem frontal cortex of patients with bipolar disorder and schizophrenia [33-35]. It is important to note that ETC complex I is one of the major sources of ROS in mitochondria. Moreover, the expression levels of NADH:Ubiquinone oxidoreductase core subunit v2 (NDUFV2), a mitochondrial complex I subunit gene, were decreased in lymphoblastoid cell lines derived from patients with bipolar disorder [36]. These findings indicate that mitochondria dysfunction is a major factor that contributes to the development of mental disorders, including bipolar disorder and schizophrenia [19]. Another important feature of the brains of patients with mental disorders is an imbalance in the levels of dopamine and glutamate (for a review, see [37]). Accumulating evidence suggests that hypofunction of NMDA receptors was observed in schizophrenia [38, 39]. Several NMDA receptor antagonists (e.g., phencyclidine and ketamine) therefore have been shown to induce schizophrenia-like symptoms [40, 41]. Other 
Table 2 Pathways interacting with DISC1 and/or TRAX

\begin{tabular}{|c|c|c|c|c|}
\hline Pathway & Binding partner & Full name & Interaction with TRAX & Interaction with DISC1 \\
\hline \multirow[t]{8}{*}{$\overline{C A M P / P K A}$} & $A_{2 A} R[5,132,134]$ & $\mathrm{A}_{2 \mathrm{~A}}$ adenosine receptor & $+[132]$ & $\mathrm{Nd}$ \\
\hline & Akap9 [168] & A-Kinase Anchoring Protein 9 & $+[168]$ & $+[194,195]$ \\
\hline & ATF4 & Activating Transcription Factor 4 & nd & $+[194,196,197]$ \\
\hline & ATF5 & Activating Transcription Factor 5 & nd & $+[194,198-200]$ \\
\hline & ATF7IP & Activating Transcription Factor 7 & nd & $+[194]$ \\
\hline & $\mathrm{D} 2 \mathrm{R}$ & Dopamine D2 receptor & nd & $+[146]$ \\
\hline & PDE4B & Phosphodiesterase 4B & nd & $+[8,194,201]$ \\
\hline & PDE4D & Phosphodiesterase 4D & nd & $+[194,202]$ \\
\hline \multirow[t]{5}{*}{ Wnt signaling } & GSK3 $\beta[5]$ & Glycogen Synthase Kinase $3 \beta$ & $+[5]$ & $+[5,7,194]$ \\
\hline & $\beta$-catenin & Catenin $\beta-1$ & nd & $+[7,194,203]$ \\
\hline & DIXDC1 & DIX Domain Containing 1 & nd & $+[194,204]$ \\
\hline & TNIK & TRAF2 And NCK Interacting Kinase & nd & $+[194,205,206]$ \\
\hline & WNT3A & Wnt Family Member 3A & nd & $+[194]$ \\
\hline \multirow[t]{10}{*}{ Intracellular Transport } & Dynactin & Dynactin & nd & $+[207]$ \\
\hline & FEZ1 & Fasciculation And Elongation Protein Zeta 1 & nd & $+[208,209]$ \\
\hline & $\mathrm{HZF}$ & Haematopoetic zinc finger & nd & $+[12]$ \\
\hline & $\mathrm{KIF} 1 \mathrm{~B}$ & Kinesin Family Member 1B & nd & $+[12]$ \\
\hline & $\mathrm{KIF} 2 \mathrm{~A}$ & Kinesin Family Member 2A & $+[134,183]$ & nd \\
\hline & $\mathrm{KIF} 5 \mathrm{~A}$ & Kinesin Family Member $5 \mathrm{~A}$ & nd & $+[11,12]$ \\
\hline & Miro1/2 & Mitochondrial Rho GTPase 1/2 & nd & $+[9,210]$ \\
\hline & SNPH & Syntaphilin & nd & $+[10]$ \\
\hline & TRAK1/2 & Trafficking kinesin protein-1/2 & nd & $+[9]$ \\
\hline & Translin & Tanslin & $+[211]$ & nd \\
\hline \multirow[t]{3}{*}{ DNA repair } & ATM & ataxia-telangiectasia mutated & $+[137]$ & nd \\
\hline & C1D & nuclear matrix protein C1D & $+[136]$ & nd \\
\hline & $\operatorname{Rad} 21$ & Double-strand-break repair protein rad21 homolog & $\mathrm{Nd}$ & $+[212,213]$ \\
\hline
\end{tabular}

Accumulating evidence suggests the involvement of DISC1/TRAX in several signaling pathways and machineries that mediate a wide variety of cellular functions. + , direct interaction. nd, not determined. The corresponding references are listed in parentheses

studies reported that hypofunction of synaptic NMDA receptors are detrimental to neurons. Activation of synaptic NMDA receptors promotes signaling pathways that have been implicated in neuronal survival [42]. Thus, the enhancement of NMDA receptor function may serve as a potential therapeutic strategy for patient with schizophrenia. It should be noted that excess glutamate causes calcium influx and subsequently facilitates the generation of ROS [43, 44].

In addition to high oxidative stress levels, impaired DNA repair is also a pathogenic feature of mental disorders [1]. Many genes involved in DNA repair or DNA damage detection have also been implicated in mental disorders. For example, variants of genes involved in DNA repair, such as $\mathrm{x}$-ray repair cross complementing 1 (XRCC1), XRCC3, human 8-oxoguanine DNA $\mathrm{N}$-glycosylase 1 (hOGG1), and xeroderma pigmentosum group D (XPD), have been documented in schizophrenia pathophysiology [2]. Improving DNA repair is thus a possible strategy for developing therapeutic interventions for mental disorders. In the present review, the emerging role of a new set of risk genes (DISC1, GSK3 $\beta$, and TRAX) for mental disorders in the repair of oxidative DNA damage will be discussed.

\section{GSK3}

GSK3 was originally identified as a highly specific serine/threonine kinase for glycogen synthase in rabbit skeletal muscle [45]. There are two types of GSK3, GSK3 $\alpha$ and GSK3 $\beta$, and these are encoded by two different genes that share $83 \%$ identity in humans [46]. GSK3 activity can be regulated positively by the phosphorylation of GSK3 $\alpha$ and GSK3 $\beta$ at $\mathrm{Tyr}^{279}$ and $\mathrm{Tyr}^{216}$, respectively [47], and negatively by the phosphorylation of GSK3 $\alpha$ and GSK3 $\beta$ at $\operatorname{Ser}^{21}$ and Ser ${ }^{9}$, respectively $[48,49]$. The phosphorylation of $\mathrm{Tyr}^{279}$-GSK3 $\alpha$ and $\mathrm{Tyr}^{216}$-GSK3 $\beta$ are intramolecular autophosphorylation events [50], whereas the phosphorylation of $\mathrm{Ser}^{21}$-GSK3 $\alpha$ and $\mathrm{Ser}^{9}$ - 
GSK3 $\beta$ can be mediated by several kinases, including AKT [51] and protein kinase A (PKA) [52]. Both GSK3 $\alpha$ and GSK3 $\beta$ are expressed highly in the mouse brain [53], whereas GSK3 $\beta$ is mainly expressed in the human brain [54]. GSK3 $\beta$ is thus expected to play a critical role in the brain.

As a kinase, GSK3 $\beta$ is involved in diverse biological activities and pathways by phosphorylating its downstream substrates. Briefly, GSK3 $\beta$ regulates neurite outgrowth, neuronal polarization and microtubule dynamics by phosphorylating several microtubule-associated proteins (MAPs), such as tau [55], MAP1 $\beta$ [56] and collapsin response mediator protein-2 (CRMP-2) [57]. GSK3 $\beta$ also regulates structural synaptic plasticity. GSK3 $\beta$ phosphorylates $\beta$-catenin and promotes $\beta$-catenin degradation [58]. GSK3 $\beta$ deletion in a subset of cortical and hippocampal neurons results in constitutively active $\beta$-catenin, which reduces spine density and excitatory synaptic neurotransmission [59]. GSK3 $\beta$ deletion in dentate gyrus (DG) excitatory neurons also reduces the levels of several synaptic proteins and subunits of N-methyl-D-aspartate (NMDA) and $\alpha$-amino-3-hydroxy-5-methyl-4- isoxazolepropionic acid (AMPA) receptors and inhibits calcium/calmodulin-dependent protein kinase II (CaMKII)/CaMKIV-cAMP response element binding protein (CREB) signaling [60]. Furthermore, GSK3 $\beta$ is involved in long-term potentiation (LTP) and long-term depression (LTD). During LTP induction in the DG and CA1 areas of the hippocampus, the phosphorylation level of GSK3 $\beta$ at $\mathrm{Ser}^{9}$ is increased, which subsequently inhibits the induction of LTD [61-63]. GSK3 $\beta$ overexpression in the hippocampus reduces neurotransmitter release and hyper-phosphorylates tau, which impairs the induction of LTP and learning $[64,65]$. In addition, GSK3 inhibition rescues the number of abnormal dendritic spines and glutamatergic synapses in pyramidal neurons and may improve the psychiatric pathogenesis caused by DIXDC1/GSK3 axis impairment in mental disorders [66].

GSK3 $\beta$ is also involved in apoptotic regulation in response to several stresses, including DNA damage [67] and oxidative stress [68]. In response to DNA damage, the interaction between GSK3 $\beta$ and p53 enhances the activity of GSK3 $\beta$ and p53-mediated apoptosis via increasing p21 protein levels and caspase-3 activation [67]. GSK3 $\beta$ inactivation protects hippocampal [69] and cerebellar granule neurons [70] from irradiation-induced death through inhibiting p53 accumulation [71]. In neurons, oxidative stress exposure for a short period of time reduces the activity of GSK3 $\beta$, while prolonged exposure to ROS increases GSK3 $\beta$ activity [72, 73]. Therefore, GSK3 $\beta$ is a redox-sensitive kinase. GSK3 $\beta$ activation in response to oxidative stress downregulates the nuclearlocalized NF-E2-related factor 2 (NRF2), which inhibits the expression of antioxidant genes, such as heme oxygenase-1 (HO-1), and sensitizes neurons to oxidative stress-induced death [72]. Furthermore, GSK3 $\beta$ activation in response to oxidative stress phosphorylates and induces the degradation of CRMP-2, a cytoskeleton regulator involved in lithium response in bipolar disorder patients [74], and results in axonal degeneration and neuronal death [73, 75]. GSK3 $\beta$ inhibition is thus expected to protect neurons from oxidative stress-induced damage and death. Consistently, GSK3 $\beta$ inhibition through activating $\mathrm{A}_{2 \mathrm{~A}}$ adenosine receptor $\left(\mathrm{A}_{2 \mathrm{a}} \mathrm{R}\right)$ has protective effects on oxidative stress-induced DNA damage because its binding partner (TRAX) is released to facilitate DNA repair and improve survival [5].

Accumulating evidence suggests that the dysregulation of GSK3 $\beta$ and/or its up/downstream molecules may contribute to bipolar disorder and schizophrenia. The inhibitory phosphorylation levels of GSK3 are lower in the peripheral blood mononuclear cells (PBMCs) from bipolar disorder patients than in those from healthy controls [76], but not in platelets [77]. Interestingly, although the protein levels of GSK3 are higher in PBMCs from type 1 bipolar disorder patients than in those from normal subjects, the amount of inhibitory GSK3 phosphorylation shows only a decreasing trend [78]. Conversely, the protein levels of GSK3 $\beta$ in the frontal cortex and cerebrospinal fluid are lower in schizophrenia patients than in normal subjects $[79,80]$. However, other studies have failed to show changes in the protein levels or activity of GSK3 $\beta$ in patients with mental diseases compared to normal controls [81, 82].

One reason that GSK3 $\beta$ is linked to psychiatric diseases is that GSK3 is a target of lithium, a mood stabilizer used to treat mental diseases [83]. Lithium enhances the phosphorylation of GSK3 $\beta$ at $\mathrm{Ser}^{9}$ to inhibit GSK3 $\beta$ directly through competition with magnesium [84] and indirectly by activating AKT [85]. Significant efforts have thus been devoted to the design and development of new GSK3 inhibitors [86-89]. Several new GSK3 inhibitors have been assessed in mouse models of bipolar diseases. For example, the maleimide derivative, 3-(Benzofuran-3-yl)-4-(indol-3-yl)maleimide compound $2 \mathrm{~B}$, which mimics the structure of lithium, inhibits GSK3 $\beta$ activity and locomotor hyperactivity induced by the combination of amphetamine and chlordiazepoxide as a model for the manic phase of bipolar disease [90]. Additional GSK3 inhibitors (including indirubin, alsterpaullone, TDZD-8, AR-A014418, SB216763, and SB-627772) were shown to inhibit rearing hyperactivity in the amphetamine-induced hyperactivity [91]. In the present review, we focus on a novel function of GSK3 that may provide new insights into the role of GSK3 in neuronal development and psychiatric pathogenesis. 


\section{DISC1}

DISC1 was initially identified in a large Scottish family with a spectrum of mental diseases (including schizophrenia, recurrent major depression and bipolar disorder) [92-95]. The N-terminal globular domain of DISC1 contains a conserved nuclear localization signal, and the C-terminal coiled-coil region is predicted to mediate its interactions with different proteins [96]. DISC1 is highly expressed in the heart, brain and placenta of humans [94] and in the heart, brain, kidney, and testis of mice [97]. DISC1 expression in the brain is regulated during development; its highest level occurs during the neonatal-infancy period and decreases gradually with age in human brains [98]. It is important to note that DISC1 expression may be regulated by environmental stimuli too. For example, the activation of Toll-like receptor 3 (TLR3) during viral infection leads to the downregulation of DISC1 through myeloid differentiation primary response gene 88 (MYD88) and subsequently impairs dendritic arborization and neuronal development [99]. Such cytoarchitectural defects (e.g., dendritic organization) have been found in schizophrenic subjects $[100,101]$, suggesting the importance of DISC1 in the regulation of neuronal development at prenatal and neonatal stages. Given the correlation between the deficits in neuronal development and the risk of developing schizophrenia, schizophrenia is also referred to as a neurodevelopmental disorder.

Previous studies suggest that DISC1 functions as a scaffold protein and mediates diverse neurodevelopmental processes by interacting with different proteins (Table 2). Specifically, DISC1 regulates cytoskeletal processes (e.g., neurite outgrowth and neuronal migration) by interacting with several proteins that are localized to the centrosome and axonal growth cones, including lissencephaly 1 (LIS1), nuclear distribution nudE-Like 1 (NDEL1) [11, 102], NDE1 [103], pericentriolar material 1 (PCM1), and Bardet-Biedl syndrome 4 (BBS4) [104].Given that DISC1 is located at the post-synaptic density (PSD) in the human neocortex [105], DISC1 is likely to play an important role in dendritic spine development and synaptic activities. DISC1 interacts with kalirin-7 (kal-7) at the glutamatergic PSD and mediates the interaction between kal-7 and PSD-95 or Rac family small GTPase 1 (Rac1) to regulate the size and number of spines [6].

Another important function of DISC1 is its regulation of the cyclic adenosine monophosphate (cAMP)-signaling pathway by binding and inhibiting phosphodiesterase 4B (PDE4B; Table 2). Increased cAMP levels cause DISC1 and PDE4B dissociation and enhance PDE4B activity [8]. The DISC1/PDE4 complex also regulates the PKA-mediated phosphorylation and association of a complex (NDE1/LIS1/NDEL1) important for neuronal development [106]. In addition, DISC1 interacts with several key molecules in the cAMP/PKA pathway, including an anchoring protein of PKA (A-kinase anchoring protein 9 (AKAP9); Table 2), several transcription factors (activating transcription factor 4 and 5 (ATF4 and ATF5); Table 2) that recognize the cAMP response element, and a Gi $\alpha$-coupled receptor that suppresses cAMP production upon activation (D2 dopamine receptor (D2R); Table 2).

DISC1 also plays an important role in intracellular transport (Table 2). By interacting with syntaphilin (SNPH), Mitochondrial Rho GTPase 1/2 (Miro1/2), and Trafficking kinesin protein-1/2 (TRAK1/2), DISC1 mediates the transport of mitochondria in the axons and dendrites $[4,9,10]$. DISC1 is involved in the transport of synaptic vesicles because it stabilizes the interaction between fasciculation and elongation protein zeta 1 (FEZ1) and synaptotagmin-1 (SYT-1) in the axons [107]. Moreover, DISC1 interacts with hematopoietic zinc finger (HZF) to mediate the dendritic transport of inositol-1,4,5-trisphosphate receptor type 1(ITRP1) mRNA [12].

Another important interacting protein of DISC1 is GSK3 $\beta$, as well as several proteins involved in the Wnt pathway (Table 2). The direct binding of DISC1 inhibits GSK3 $\beta$ activity [7]. The interaction between DISC1 and GSK3 $\beta$ controls the fate of neural progenitors in the ventricular zone/subventricular zone [7] and subgranular zone of the dentate gyrus [97]. GSK3 $\beta$ inhibition prevents the phosphorylation and degradation of $\beta$-catenin, its downstream target [58], resulting in increased neural progenitor proliferation [108]. Intriguingly, the phosphorylation of DISC1 at $\mathrm{Ser}^{710}$ determines the affinity of DISC1 toward its binding partners. For example, non-phosphorylated DISC1 at Ser ${ }^{710}$ inhibits GSK3 $\beta$ and subsequently activates $\beta$-catenin signaling. Conversely, the phosphorylation of DISC1 at Ser ${ }^{710}$ increases the affinity of DISC1 for another binding partner, BBS protein, which facilitates the recruitment of BBS to the centrosome and subsequently causes the transition from progenitor proliferation to neuronal migration in the developing cortex [109]. It is interesting to note that the PKA-mediated inhibitory phosphorylation of GSK3 $\beta$ at $\mathrm{Ser}^{9}$ leads to the dissociation of the DISC1/GSK3 $\beta /$ TRAX complex and facilitates TRAX-mediated DNA repair in neurons [5]. These results collectively suggest that phosphorylation is a key modulatory mechanism that regulates the complex formation of DISC1 and other interaction proteins through which a wide variety of cellular functions are regulated.

Ample genetic evidence links DISC1 with major mental illnesses. The balanced $(1 ; 11)$ translocation of DISC1 within a Scottish family increased the incidence of major mental illnesses [95], probably due to the decrease in DISC1 protein levels [8] or the production of a 
dominant-negative C-terminal truncated DISC1 that loses its interaction with DISC1-interacting proteins $[110,111]$. In addition, expression levels of the DISC1interacting proteins LIS1 and NDEL1 are decreased in the brains of schizophrenia patients and are associated with high-risk DISC1 SNPs [98]. To date, the DISC1 gene has been identified as a risk factor for major mental illnesses [13, 112-120]. In contrast, some other reports have failed to show the association between DISC1 variants and mental diseases [121-123]. Further investigations of the roles of DISC1 in mental disorders are needed.

\section{TRAX}

TRAX was first discovered as a binding partner of translin using a yeast two-hybrid system. Amino acid sequence alignment revealed that TRAX displays $28 \%$ identity with translin [16]. Because the genetic removal of translin promotes the degradation of TRAX, TRAX stability appears to be controlled by its binding partner (i.e., translin [124]). Both TRAX and translin are highly enriched in the brain. The heteromeric complex composed of TRAX and translin shows nucleic acid binding activity in brain extracts
[125] and plays a role in dendritic RNA trafficking in neurons $[126,127]$. The heteromeric translin/TRAX complex also functions as an endoribonuclease that cleaves passenger strands of siRNA and therefore facilities siRNA guide strand loading onto the RNA-induced silencing complex (RISC) in Drosophila [128]. In contrast, the TRAX/translin complex suppresses microRNA (miRNA)-mediated silencing in mammalian cells by degrading pre-miRNA with mismatched stems and subsequently reversing miRNA-mediated silencing [129] (Fig. 1). In support of this hypothesis, TRAX/translin was recently shown to play a critical role in regulating long-term memory by suppressing microRNA silencing at activated synapses [130]. Given that aberrant profiles of miRNAs and their targeted genes have been implicated in mental disorders (such as schizophrenia, bipolar disorder and autism) (for a review, see [131]), the role of abnormal TRAX/translin regulation in mental disorders warrants future investigations.

Similar to DISC1, TRAX also has many interacting proteins with a wide variety of functions. Most of these TRAX-interacting proteins are risk genes, markers, or

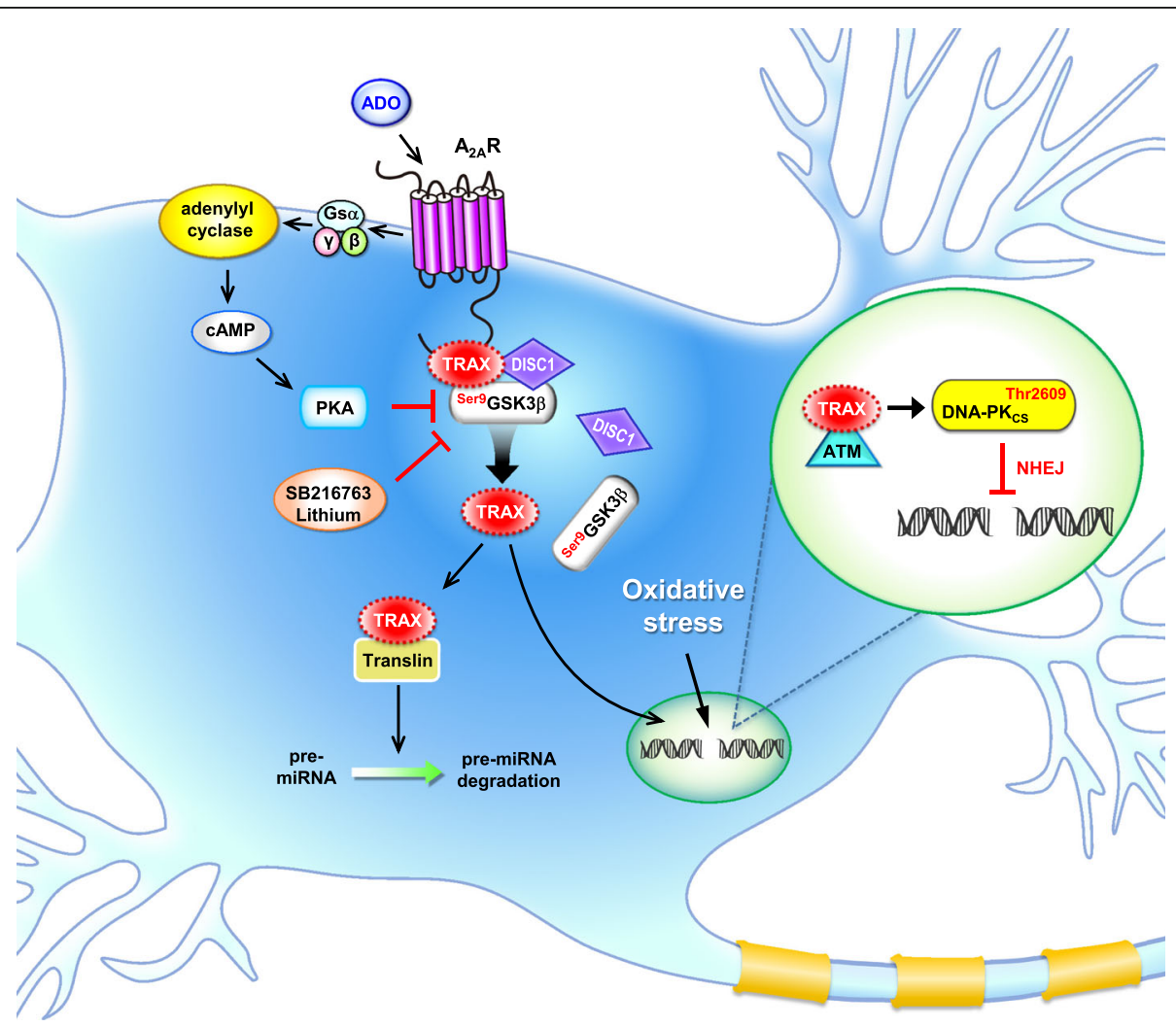

Fig. 1 A schematic representation showing the major functions of TRAX and its interacting proteins. In neurons, TRAX interacts with the $C$ terminus of the $A_{2 A}$ adenosine receptor $\left(A_{2 A} R\right)$, a Gsa-coupled receptor that activates adenylyl cyclase to produce cAMP upon stimulation with adenosine (ADO). At the resting stage, TRAX forms complexes with GSK3 $\beta$ and DISC1. High oxidative stress is known to cause double-strand DNA breaks. Activating the $A_{2 A} R / P K A$-dependent pathway or inhibiting GSK3 3 using selective inhibitors (e.g., SB216763 or lithium) release TRAX from the complex and assist in ATM/DNA-PK-dependent non-homologous end joining (NHEJ) repair in the nuclei $[5,137]$. TRAX may also bind with translin to regulate the amount of miRNA and downstream gene expression profiles [130]. 
drug targets for psychotic disorders (e.g., schizophrenia, autism, and panic disorders; Table 1). For example, $A_{2 A} R$ is the binding partner of TRAX [132]. $A_{2 A} R$ is a Gs $\alpha$-coupled receptor that activates the cAMP/PKA pathway upon stimulation [133]. $\mathrm{A}_{2 \mathrm{~A}} \mathrm{R}$ activation or TRAX overexpression rescues the impaired neurite outgrowth caused by p53 blockade in a neuronal cell line (PC12) and primary hippocampal neurons. Knocking down TRAX or preventing the interaction between TRAX and its interacting protein (kinesin heavy chain member 2A, KIF2A) blocks the rescue effect of $A_{2 A} R$ activation [134]. Of note, KIF2A is a schizophrenia susceptibility gene [135]. $A_{2 A} R$ is a risk gene for autism and anxiety disorders, and a marker for schizophrenia (Table 1).

Two of the TRAX-interacting proteins (C1D and ataxia-telangiectasia mutated (ATM) kinase) are involved directly in DNA repair. C1D is an activator of DNAdependent protein kinase (DNA-PK). Upon DNA damage induced by $\gamma$-irradiation, TRAX increasingly interacts with C1D in mammalian cells, suggesting that TRAX might participate in DNA repair [136]. ATM is a serine/threonine kinase and is activated and recruited by DNA double-strand breaks (DSBs) to phosphorylated proteins (e.g., histone $\mathrm{H} 2 \mathrm{~A}(\mathrm{H} 2 \mathrm{AX})$ and p53) that are important for DNA repair. In the absence of TRAX, ATM fails to be recruited to DSB sites to initiate the DNA repair machinery and subsequently causes cell death due to insufficient DNA damage repair $[5,137]$. During oxidative stress-induced DNA damage in neurons, TRAX forms a complex with DISC1 and GSK3 $\beta$ in the cytoplasmic region. $\mathrm{A}_{2 \mathrm{~A}} \mathrm{R}$ stimulation activates PKA, which phosphorylates GSK3 $\beta$ at $\operatorname{Ser}^{9}$ and dissociates the TRAX/DISC1/GSK3 $\beta$ complex so that TRAX can enter the nuclei to facilitate DNA repair [5] (Fig. 1). The role of TRAX and its interacting proteins in mental disorders appear important because ample evidence suggests that incomplete oxidative DNA damage repair may contribute to the development of psychotic disorders $[1,17,18]$. Most of the major components (including ATM, [138, 139]) involved in TRAX-mediated DNA repair are also risk genes of mental disorders (Table 1).

Consistent with the hypothesis that TRAX is involved in the development of mental disorders, genetic studies have implicated TRAX in major psychiatric diseases. The human TSNAX gene is located at 1q42.1 and adjacent to the DISC1 gene. Several TSNAX transcripts contain the DISC1 sequence at the 3' end due to intergenic splicing in human adult and fetal tissues [93]. A SNP analysis revealed that 2 SNPs (i.e., rs1615409 and rs766288) are located within intron 4 of TSNAX, and 2 SNPs (i.e., rs751229 and rs3738401) were found in DISC1 in Finnish schizophrenia patients [13]. A rare AATG haplotype comprising these 4 SNPs is positively associated with the reaction time to visual targets and negatively with the gray matter density in Finnish schizophrenia patients [140]. Furthermore, another SNP analysis identified that rs 1655285 at intron 5 of TSNAX and a haplotype comprising rs1630250 and rs1615409 within TSNAX are associated with Finnish bipolar spectrum disorder [15]. The SNP rs766288 at intron 4 of TSNAX has been reported to be associated with Japanese female major depressive disorder [14]. These studies collectively suggest that TRAX is a risk gene for major mental diseases. It should also be noted that TRAX and DISC1 share several interacting proteins (e.g., GSK3 $\beta$ and AKAP9; Table 2) and functional pathways/machineries (e.g., the cAMP/PKA pathway, Wnt signaling, intracellular transport and DNA repair; Table 2); thus, they may act together to regulate important pathophysiological events, including the development of mental disorders.

\section{Regulation of the TRAX/DISC1/GSK3 $\beta$ complex and therapeutic relevance}

Although DISC1 mediates many different cellular functions, it has not been implicated in DNA repair until a recent report [5] demonstrating that DISC1 interacts with GSK3 $\beta$ and TRAX; this complex facilitates DNA repair by binding to ATM [137]. This finding leads to a new mechanistic role of DISC1 in mental disorders in which accumulating oxidative DNA damage and insufficient DNA repair contribute to the pathogenesis $[1,17,18]$. Disassembly of the TRAX/DISC1/GSK3 $\beta$ complex, followed by the release of TRAX, provides a new means to facilitate DNA repair and ameliorate the damage caused by unrepaired DSBs. For example, $\mathrm{A}_{2 \mathrm{~A}} \mathrm{R}$ activation dissociates TRAX/DISC1/GSK3 $\beta$ complex tethering at its $C$ terminus through a PKA-dependent pathway and amends the DNA damage-induced apoptosis [5]. Consistent with an important role of $A_{2 A} R$ in facilitating DNA repair, $\mathrm{A}_{2 \mathrm{~A}} \mathrm{R}$ activation ameliorates oxidative DNA damage in human medium spiny neurons (MSNs) derived from induced pluripotent stem cells (iPSCs) [141]. Interestingly, the amount of $\mathrm{A}_{2 \mathrm{~A}} \mathrm{R}$ is altered in different brain regions of patients with schizophrenia [142, 143], supporting that $\mathrm{A}_{2 \mathrm{~A}} \mathrm{R}$ might play an important role in schizophrenia. Because $A_{2 A} R$ is an antagonistic binding partner of the D2R and may suppress the hyperfunction of D2R in schizophrenia [144], $\mathrm{A}_{2 \mathrm{~A}} \mathrm{R}$ agonists are potentially advantageous anti-schizophrenic drugs (for a review, see [145]). D2R is a primary target of antipsychotic drugs. It forms complex with not only $\mathrm{A}_{2 \mathrm{~A}} \mathrm{R}$ but also DISC1 to mediate the D2R-dependent activation of GSK3 $\beta$ [146]. This is of great interest because DISC1 binds with TRAX and GSK3 $\beta$ [5]. Whether D2R activation affects the accumulation of oxidative DNA damage and contributes to pathogenesis requires further investigation. 
It is important to note that adenosine is known to regulate the dopamine and glutamate- mediated neurotransmissions, the major neurotransmitter systems involved in schizophrenia pathophysiology [147-149]. Dysfunction of purinergic system is one of the factors that cause schizophrenia $[149,150]$. Moreover, inhibition of adenosine kinase (ADK), which controls adenosine level, exhibits anti-psychotic-like efficacy, while overexpression of ADK causes changes in the sensitivity to psychomimetic drugs in mice $[151,152]$. Consistent with the abovementioned hypothesis, increased brain adenosine tone using an inhibitor of adenosine uptake (i.e., dipyridamole) indirectly activates adenosine receptors and hasWr beneficial effects on patients with schizophrenia [153]. Likewise, inhibiting adenosine clearance using ABT702 to globally increase adenosine tone also ameliorates the psychotic and cognitive phenotypes of schizophrenia in mice [151]. Given that adenosine is also known to play an important role during neurodevelopment. (for a review, see [154]). Augmenting the adenosine tone in the brain using various approaches might thus serve as a therapeutic means to treat schizophrenia as well as to prevent the development of schizophrenia [154, 155].

Lithium is an inhibitor of GSK3 and a common mood stabilizer for treating mental disorders. To date, the underlying molecular mechanism of lithium's action remains largely elusive [156, 157]. Accumulating evidence suggests that chronic treatment with lithium inhibits the oxidative damage evoked by glutamate [158] and increases the expression level of the anti-apoptotic factor Bcl2 [159, 160]. Treatment with lithium also protects neurons by facilitating the NHEJ repair-mediated DNA repair pathway [161]. Chronic treatment with lithium results in not only the inhibition of GSK3 $\beta$ but also the regulation of many anti-apoptotic proteins. For example, lithium inhibits calcium influx via regulating the NMDA receptor and reduces apoptosis by directly inhibiting GSK3 $\beta$ [162]. Because inhibiting GSK3 $\beta$ causes the disassembly of the TRAX/DISC1/GSK3 $\beta$ complex and releases TRAX to facilitate DNA repair [5], at least part of the actions of lithium might be mediated by the TRAX/DISC1/GSK3 $\beta$ complex. New GSK3 $\beta$ inhibitors have been actively developed for brain diseases [163], which may pave the way for establishing new treatments for schizophrenia.

\section{Conclusions}

As a major gene implicated in schizophrenia and other mental disorders, DISC1 is known to regulate various cellular functions by interacting with proteins of different machineries. Ample evidence suggests that DISC1 is a hub protein for schizophrenia and possibly other mental diseases. Emerging evidence also suggests that
TRAX, a neighboring gene of DISC1, not only physically interacts with DISC1 but also switches binding partners under different pathophysiological conditions as does DISC1. Because the studies regarding TRAX are still in their infancy, the overlapping functional pathways of DISC1 and TRAX appear limited at this time (Table 2) but may become more evident when more binding partners of TRAX are revealed in the future. Most importantly, genetic evidence suggests that DISC1 and TRAX are closely associated with several major mental disorders (such as schizophrenia, autism, and anxiety disorder; Table 1). Therefore, it is certainly worth further exploring the role of the DISC1/TRAX complex in psychiatric disorders. Because oxidative DNA damage accumulation and insufficient DNA repair have been implicated in the development and progression of mental disorders, the recently reported function of the DISC1/ TRAX/GSK3 $\beta$ complex in DNA repair also warrants further investigations of the temple and the special regulation of this complex during neuronal development and disease progression. Further understanding of when and where the DISC1/TRAX/GSK3 $\beta$ complex is formed and how the complex can be effectively dissembled by either GSK3 $\beta$ inhibitors or PKA activators (such as $\mathrm{A}_{2 \mathrm{~A}} \mathrm{R}$ agonists or PDE4 inhibitors) would pave the way for developing new therapeutic agents for mental disorders.

\section{Abbreviations}

8-OHdG: 8-hydroxy-2'-deoxyguanosine; $\mathrm{A}_{2 \mathrm{a}} \mathrm{R}: \mathrm{A}_{2 \mathrm{~A}}$ adenosine receptor; ADK: Adenosine kinase; ADO: Adenosine; AKAP9: A-kinase anchoring protein 9; AMPA: a-amino-3-hydroxy-5-methyl-4- isoxazolepropionic acid; ATF: Activating transcription factor; ATM: Ataxia-telangiectasia mutated; BBS4: Bardet-Biedl syndrome 4; C1D: Nuclear matrix protein C1D;

CAMP: Cyclic adenosine monophosphate; CREB: Calcium/calmodulindependent protein kinase II (CaMKII)/CaMKIV-cAMP response element binding protein; CRMP-2: Collapsin response mediator protein-2; D2R: D2 Dopamine receptor; DG: Dentate gyrus; DISC1: Disrupted in schizophrenia 1; DIXDC1: DIX domain containing 1; DNA-PK: DNA- dependent protein kinase; DSBs: DNA double-strand breaks; ETC: Electron transport chain;

FEZ1: Fasciculation and elongation protein zeta 1; GSK3: Glycogen synthase kinase 3; H2AX: Histone H2A; HO-1: Heme oxygenase-1; hOGG1: Human 8oxoguanine DNA N-glycosylase 1; HZF: Hematopoietic zinc finger; iPSCs: Induced pluripotent stem cells; ITRP1: Inositol-1,4,5-trisphosphate receptor type 1; kal-7: Kalirin-7; KIF2A: Kinesin heavy chain member 2A; LIS1: Lissencephaly 1; LTD: Long-term depression; LTP: Long-term potentiation; MAPs: Microtubule-associated proteins; MEA2: Male-enhanced antigen 2; miRNA: microRNA; Miro1/2: Mitochondrial Rho GTPase 1/2; MSNs: Medium spiny neurons; MYD88: Myeloid differentiation primary response gene 88; NDEL1: Nuclear distribution nudE-Like 1; NDUFV2: NADH:Ubiquinone oxidoreductase core subunit V2; NHEJ: Nonhomologous end joining; NMDA: N-methyl-D-aspartate; NRF2: Nuclearlocalized NF-E2-related factor 2; PBMCs: Peripheral blood mononuclear cells; PCM1: Pericentriolar material 1; PCP: Phencyclidine;

PDE4B: Phosphodiesterase 4B; PKA: Protein kinase A; PLCB1: Phospholipase C Beta 1; PSD: Post-synaptic density; Rac1: Rac family small GTPase 1;

Rad21: Double-strand-break repair protein rad21 homolog; RISC: RNAinduced silencing complex; ROS: Reactive oxygen species; SNPH: Syntaphilin; SUN1: SUN domain-containing protein 1; SYT-1: Synaptotagmin-1; TLR3: Tolllike receptor 3; TNIK: TRAF2 and NCK interacting kinase; TRAK1/2: Trafficking kinesin protein-1/2; TRAX: Translin-associated factor X; WNT3A: Wnt family member 3A; XPD: Xeroderma pigmentosum group D; XRCC: X-ray repair cross complementing 


\section{Acknowledgments}

We thank Mr. Tsung Hung Hung at the Medical Art Room of Institute of Biomedical Sciences, Academia Sinica for the preparation of Fig. 1.

\section{Funding}

This work was supported by the Institute of the Biomedical Sciences of Academia Sinica (103-Academia Sinica Investigation Award-06).

\section{Authors' contributions}

YC outlined and wrote the manuscript. YTW wrote part of the manuscript and prepared the tables. TC wrote part of the manuscript and prepared the figure and table. IIK analyzed literatures and prepared tables. All authors read and approved the final manuscript.

\section{Ethics approval and consent to participate} Not applicable.

\section{Consent for publication}

Not applicable.

\section{Competing interests}

The authors declare that they have no competing interests.

\section{Publisher's Note}

Springer Nature remains neutral with regard to jurisdictional claims in published maps and institutional affiliations.

\section{Received: 7 June 2018 Accepted: 25 September 2018}

\section{Published online: 04 October 2018}

\section{References}

1. Markkanen E, Meyer U, Dianov GL. DNA Damage and Repair in Schizophrenia and Autism: Implications for Cancer Comorbidity and Beyond. Int J Mol Sci. 2016;17(6):856.

2. Odemis S, Tuzun E, Gulec H, Semiz UB, Dasdemir S, Kucuk M, Yalcinkaya N, Bireller ES, Cakmakoglu B, Kucukali Cl. Association between polymorphisms of DNA repair genes and risk of schizophrenia. Genet Test Mol Biomarkers. 2016;20(1):11-7.

3. Raza MU, Tufan T, Wang Y, Hill C, Zhu MY. DNA damage in major psychiatric diseases. Neurotox Res. 2016;30(2):251-67.

4. Atkin TA, MacAskill AF, Brandon NJ, Kittler JT. Disrupted in Schizophrenia-1 regulates intracellular trafficking of mitochondria in neurons. Mol Psychiatry. 2011;16(2):122-4.

5. Chien T, Weng YT, Chang SY, Lai HL, Chiu FL, Kuo HC, Chuang DM, Chern Y. GSK3beta negatively regulates TRAX, a scaffold protein implicated in mental disorders, for NHEJ-mediated DNA repair in neurons. Mol Psychiatry. 2018. https://doi.org/10.1038/s41380-017-0007-z.

6. Hayashi-Takagi A, Takaki M, Graziane N, Seshadri S, Murdoch H, Dunlop AJ, Makino Y, Seshadri AJ, Ishizuka K, Srivastava DP, Xie Z, Baraban JM, Houslay MD, Tomoda T, Brandon NJ, Kamiya A, Yan Z, Penzes P, Sawa A. Disruptedin-schizophrenia 1 (DISC1) regulates spines of the glutamate synapse via Rac1. Nat Neurosci. 2010;13(3):327-32.

7. Mao Y, Ge X, Frank CL, Madison JM, Koehler AN, Doud MK, Tassa C, Berry EM, Soda T, Singh KK, Biechele T, Petryshen TL, Moon RT, Haggarty SJ, Tsai $\mathrm{LH}$. Disrupted in schizophrenia 1 regulates neuronal progenitor proliferation via modulation of GSK3beta/beta-catenin signaling. Cell. 2009;136(6):1017-31.

8. Millar JK, Pickard BS, Mackie S, James R, Christie S, Buchanan SR, Malloy MP, Chubb JE, Huston E, Baillie GS, Thomson PA, Hill EV, Brandon NJ, Rain JC, Camargo LM, Whiting PJ, Houslay MD, Blackwood DH, Muir WJ, Porteous DJ. DISC1 and PDE4B are interacting genetic factors in schizophrenia that regulate CAMP signaling. Science. 2005;310(5751):1187-91.

9. Norkett R, Modi S, Birsa N, Atkin TA, Ivankovic D, Pathania M, Trossbach SV Korth C, Hirst WD, Kittler JT. DISC1-dependent regulation of mitochondrial dynamics controls the morphogenesis of complex neuronal dendrites. J Biol Chem. 2016;291(2):613-29.

10. Park C, Lee SA, Hong JH, Suh Y, Park SJ, Suh BK, Woo Y, Choi J, Huh JW, Kim YM, Park SK. Disrupted-in-schizophrenia 1 (DISC1) and Syntaphilin collaborate to modulate axonal mitochondrial anchoring. Mol Brain. 2016;9(1):69

11. Taya S, Shinoda T, Tsuboi D, Asaki J, Nagai K, Hikita T, Kuroda S, Kuroda K, Shimizu M, Hirotsune S, Iwamatsu A, Kaibuchi K. DISC1 regulates the transport of the NUDEL/LIS1/14-3-3epsilon complex through kinesin-1. J Neurosci. 2007;27(1):15-26.

12. Tsuboi D, Kuroda K, Tanaka M, Namba T, lizuka Y, Taya S, Shinoda T, Hikita T, Muraoka S, lizuka M, Nimura A, Mizoguchi A, Shiina N, Sokabe M, Okano H, Mikoshiba K, Kaibuchi K. Disrupted-in-schizophrenia 1 regulates transport of ITPR1 mRNA for synaptic plasticity. Nat Neurosci. 2015;18(5):698-707.

13. Hennah W, Varilo T, Kestila M, Paunio T, Arajarvi R, Haukka J, Parker A, Martin R, Levitzky S, Partonen T, Meyer J, Lonnqvist J, Peltonen L, Ekelund J. Haplotype transmission analysis provides evidence of association for DISC1 to schizophrenia and suggests sex-dependent effects. Hum Mol Genet. 2003:12(23):3151-9.

14. Okuda A, Kishi T, Okochi T, Ikeda M, Kitajima T, Tsunoka T, Okumukura T, Fukuo Y, Kinoshita Y, Kawashima K, Yamanouchi Y, Inada T, Ozaki N, Iwata N. Translin-associated factor $X$ gene (TSNAX) may be associated with female major depressive disorder in the Japanese population. NeuroMolecular Med. 2010;12(1):78-85.

15. Palo OM, Antila M, Silander K, Hennah W, Kilpinen H, Soronen P, TuulioHenriksson A, Kieseppa T, Partonen T, Lonnqvist J, Peltonen L, Paunio T. Association of distinct allelic haplotypes of DISC1 with psychotic and bipolar spectrum disorders and with underlying cognitive impairments. Hum Mol Genet. 2007:16(20):2517-28.

16. Aoki K, Ishida R, Kasai M. Isolation and characterization of a CDNA encoding a Translin-like protein, TRAX. FEBS Lett. 1997;401(2-3):109-12.

17. Steckert AV, Valvassori SS, Moretti M, Dal-Pizzol F, Quevedo J. Role of oxidative stress in the pathophysiology of bipolar disorder. Neurochem Res. 2010;35(9):1295-301.

18. Wang JF, Shao L, Sun X, Young LT. Increased oxidative stress in the anterior cingulate cortex of subjects with bipolar disorder and schizophrenia. Bipolar Disord. 2009;11(5):523-9.

19. Prabakaran S, Swatton JE, Ryan MM, Huffaker SJ, Huang JT, Griffin JL, Wayland M, Freeman T, Dudbridge F, Lilley KS, Karp NA, Hester S, Tkachev D, Mimmack ML, Yolken RH, Webster MJ, Torrey EF, Bahn S. Mitochondrial dysfunction in schizophrenia: evidence for compromised brain metabolism and oxidative stress. Mol Psychiatry. 2004;9(7):684-97.

20. Kavanagh JN, Redmond KM, Schettino G, Prise KM. DNA double strand break repair: a radiation perspective. Antioxid Redox Signal. 2013;18(18):2458-72.

21. Mariani E, Polidori MC, Cherubini A, Mecocci P. Oxidative stress in brain aging, neurodegenerative and vascular diseases: an overview. J Chromatogr B Analyt Technol Biomed Life Sci. 2005;827(1):65-75.

22. Chestkov IV, Jestkova EM, Ershova ES, Golimbet VG, Lezheiko TV, Kolesina NY, Dolgikh OA, Izhevskaya VL, Kostyuk GP, Kutsev SI, Veiko NN, Kostyuk SV. ROS-induced DNA damage associates with abundance of mitochondrial DNA in white blood cells of the untreated schizophrenic patients. Oxidative Med Cell Longev. 2018;8587475:2018.

23. Hassan W, Noreen H, Castro-Gomes V, Mohammadzai I, da Rocha JB, Landeira-Fernandez J. Association of Oxidative Stress with psychiatric disorders. Curr Pharm Des. 2016:22(20):2960-74.

24. van Velzen $L S$, Wijdeveld M, Black CN, van Tol MJ, van der Wee NJA, Veltman DJ, Penninx B, Schmaal L. Oxidative stress and brain morphology in individuals with depression, anxiety and healthy controls. Prog NeuroPsychopharmacol Biol Psychiatry. 2017;76:140-4

25. Ng F, Berk M, Dean O, Bush Al. Oxidative stress in psychiatric disorders: evidence base and therapeutic implications. Int J Neuropsychopharmacol. 2008;11(6):851-76

26. Salim S. Oxidative stress and psychological disorders. Curr Neuropharmacol. 2014:12(2):140-7.

27. Salim S. Oxidative stress and the central nervous system. J Pharmacol Exp Ther. 2017:360(1):201-5

28. Ceylan D, Scola G, Tunca Z, Isaacs-Trepanier C, Can G, Andreazza AC, Young $L T$, Ozerdem A. DNA redox modulations and global DNA methylation in bipolar disorder: effects of sex, smoking and illness state. Psychiatry Res. 2018;261:589-96.

29. Chen CM, Wu YR, Cheng ML, Liu JL, Lee YM, Lee PW, Soong BW, Chiu DT. Increased oxidative damage and mitochondrial abnormalities in the peripheral blood of Huntington's disease patients. Biochem Biophys Res Commun. 2007:359(2):335-40.

30. Huang MC, Lai YC, Lin SK, Chen CH. Increased blood 8-hydroxy-2deoxyguanosine levels in methamphetamine users during early abstinence. Am J Drug Alcohol Abuse. 2018;44(3):395-402.

31. Soeiro-de-Souza MG, Andreazza AC, Carvalho AF, Machado-Vieira R, Young LT, Moreno RA. Number of manic episodes is associated with elevated 
DNA oxidation in bipolar I disorder. Int J Neuropsychopharmacol. 2013; 16(7):1505-12.

32. Deicken RF, Fein G, Weiner MW. Abnormal frontal lobe phosphorous metabolism in bipolar disorder. Am J Psychiatry. 1995;152(6):915-8.

33. Ben-Shachar D, Karry R. Sp1 expression is disrupted in schizophrenia; a possible mechanism for the abnormal expression of mitochondrial complex I genes, NDUFV1 and NDUFV2. PLoS One. 2007;2(9):e817.

34. Konradi C, Eaton M, MacDonald ML, Walsh J, Benes FM, Heckers S. Molecular evidence for mitochondrial dysfunction in bipolar disorder. Arch Gen Psychiatry. 2004;61 (3):300-8.

35. Sun X, Wang JF, Tseng M, Young LT. Downregulation in components of the mitochondrial electron transport chain in the postmortem frontal cortex of subjects with bipolar disorder. J Psychiatry Neurosci. 2006;31(3):189-96.

36. Washizuka S, Kakiuchi C, Mori K, Kunugi H, Tajima O, Akiyama T, Nanko S, Kato T. Association of mitochondrial complex I subunit gene NDUFV2 at $18 p 11$ with bipolar disorder. Am J Med Genet B Neuropsychiatr Genet. 2003:120B(1):72-8

37. Howes O, McCutcheon R, Stone J. Glutamate and dopamine in schizophrenia: an update for the 21st century. J Psychopharmacol. 2015; 29(2):97-115.

38. Banerjee A, Wang HY, Borgmann-Winter KE, MacDonald ML, Kaprielian H, Stucky A, Kvasic J, Egbujo C, Ray R, Talbot K, Hemby SE, Siegel SJ, Arnold SE, Sleiman P, Chang X, Hakonarson H, Gur RE, Hahn CG. Src kinase as a mediator of convergent molecular abnormalities leading to NMDAR hypoactivity in schizophrenia. Mol Psychiatry. 2015;20(9): 1091-100.

39. Gao XM, Sakai K, Roberts RC, Conley RR, Dean B, Tamminga CA. Ionotropic glutamate receptors and expression of $\mathrm{N}$-methyl-D-aspartate receptor subunits in subregions of human hippocampus: effects of schizophrenia. Am J Psychiatry. 2000;157(7):1141-9.

40. Farber NB. The NMDA receptor hypofunction model of psychosis. Ann N Y Acad Sci. 2003;1003:119-30.

41. Javitt DC. Glutamate and schizophrenia: phencyclidine, N-methyl-Daspartate receptors, and dopamine-glutamate interactions. Int Rev Neurobiol. 2007;78:69-108.

42. Hardingham GE, Fukunaga Y, Bading H. Extrasynaptic NMDARs oppose synaptic NMDARs by triggering CREB shut-off and cell death pathways. Nat Neurosci. 2002;5(5):405-14.

43. Hirose $\mathrm{K}$, Chan PH. Blockade of glutamate excitotoxicity and its clinical applications. Neurochem Res. 1993;18(4):479-83.

44. Zeevalk GD, Bernard LP, Sinha C, Ehrhart J, Nicklas WJ. Excitotoxicity and oxidative stress during inhibition of energy metabolism. Dev Neurosci. 1998;20(4-5):444-53.

45. Embi N, Rylatt DB, Cohen P. Glycogen synthase kinase-3 from rabbit skeletal muscle. Separation from cyclic-AMP-dependent protein kinase and phosphorylase kinase. Eur J Biochem. 1980;107(2):519-27.

46. Ali A, Hoeflich KP, Woodgett JR. Glycogen synthase kinase-3: properties, functions, and regulation. Chem Rev. 2001;101(8):2527-40.

47. Hughes K, Nikolakaki E, Plyte SE, Totty NF, Woodgett JR. Modulation of the glycogen synthase kinase-3 family by tyrosine phosphorylation. EMBO J. 1993;12(2):803-8.

48. Stambolic V, Woodgett JR. Mitogen inactivation of glycogen synthase kinase-3 beta in intact cells via serine 9 phosphorylation. Biochem J. 1994;303(Pt 3):701-4.

49. Sutherland C, Cohen P. The alpha-isoform of glycogen synthase kinase-3 from rabbit skeletal muscle is inactivated by p70 $\mathrm{S6}$ kinase or MAP kinaseactivated protein kinase-1 in vitro. FEBS Lett. 1994;338(1):37-42.

50. Cole A, Frame S, Cohen P. Further evidence that the tyrosine phosphorylation of glycogen synthase kinase-3 (GSK3) in mammalian cells is an autophosphorylation event. Biochem J. 2004;377(Pt 1):249-55.

51. Cross DA, Alessi DR, Cohen P, Andjelkovich M, Hemmings BA. Inhibition of glycogen synthase kinase-3 by insulin mediated by protein kinase B. Nature. 1995;378(6559):785-9.

52. Fang X, Yu SX, Lu Y, Bast RC Jr, Woodgett JR, Mills GB. Phosphorylation and inactivation of glycogen synthase kinase 3 by protein kinase A. Proc Natl Acad Sci U S A. 2000;97(22):11960-5.

53. Yao HB, Shaw PC, Wong CC, Wan DC. Expression of glycogen synthase kinase-3 isoforms in mouse tissues and their transcription in the brain. J Chem Neuroanat. 2002;23(4):291-7.

54. Lau KF, Miller CC, Anderton BH, Shaw PC. Expression analysis of glycogen synthase kinase-3 in human tissues. J Pept Res. 1999;54(1):85-91.
55. Cho JH, Johnson GV. Glycogen synthase kinase 3beta phosphorylates tau at both primed and unprimed sites. Differential impact on microtubule binding. J Biol Chem. 2003;278(1):187-93.

56. Lucas FR, Goold RG, Gordon-Weeks PR, Salinas PC. Inhibition of GSK-3beta leading to the loss of phosphorylated MAP-1B is an early event in axonal remodelling induced by WNT-7a or lithium. J Cell Sci. 1998; 111(Pt 10):1351-61.

57. Yoshimura T, Kawano Y, Arimura N, Kawabata S, Kikuchi A, Kaibuchi K. GSK3beta regulates phosphorylation of CRMP-2 and neuronal polarity. Cell. 2005;120(1):137-49.

58. Aberle H, Bauer A, Stappert J, Kispert A, Kemler R. Beta-catenin is a target for the ubiquitin-proteasome pathway. EMBO J. 1997;16(13):3797-804.

59. Ochs SM, Dorostkar MM, Aramuni G, Schon C, Filser S, Poschl J, Kremer A, Van Leuven F, Ovsepian SV, Herms J. Loss of neuronal GSK3beta reduces dendritic spine stability and attenuates excitatory synaptic transmission via beta-catenin. Mol Psychiatry. 2015;20(4):482-9.

60. Liu E, Xie AJ, Zhou Q, Li M, Zhang S, Li S, Wang W, Wang X, Wang Q, Wang JZ. GSK-3beta deletion in dentate gyrus excitatory neuron impairs synaptic plasticity and memory. Sci Rep. 2017;7(1):5781.

61. Cai F, Wang F, Lin FK, Liu C, Ma LQ, Liu J, Wu WN, Wang W, Wang JH, Chen JG. Redox modulation of long-term potentiation in the hippocampus via regulation of the glycogen synthase kinase-3beta pathway. Free Radic Biol Med. 2008;45(7):964-70.

62. Hooper C, Markevich V, Plattner F, Killick R, Schofield E, Engel T, Hernandez F, Anderton B, Rosenblum K, Bliss T, Cooke SF, Avila J, Lucas JJ, Giese KP, Stephenson J, Lovestone S. Glycogen synthase kinase-3 inhibition is integral to long-term potentiation. Eur J Neurosci. 2007;25(1):81-6.

63. Peineau S, Taghibiglou C, Bradley C, Wong TP, Liu L, Lu J, Lo E, Wu D, Saule E, Bouschet T, Matthews P, Isaac JT, Bortolotto ZA, Wang YT, Collingridge GL. LTP inhibits LTD in the hippocampus via regulation of GSK3beta. Neuron. 2007:53(5):703-17.

64. Gomez de Barreda E, Perez M, Gomez Ramos P, de Cristobal J, MartinMaestro P, Moran A, Dawson HN, Vitek MP, Lucas JJ, Hernandez F, Avila J. Tau-knockout mice show reduced GSK3-induced hippocampal degeneration and learning deficits. Neurobiol Dis. 2010;37(3):622-9.

65. Zhu LQ, Wang SH, Liu D, Yin YY, Tian Q, Wang XC, Wang Q, Chen JG, Wang JZ. Activation of glycogen synthase kinase-3 inhibits long-term potentiation with synapse-associated impairments. J Neurosci. 2007;27(45):12211-20.

66. Martin PM, Stanley RE, Ross AP, Freitas AE, Moyer CE, Brumback AC, lafrati J, Stapornwongkul KS, Dominguez S, Kivimae S, Mulligan KA, Pirooznia M, McCombie WR, Potash JB, Zandi PP, Purcell SM, Sanders SJ, Zuo Y, Sohal VS, Cheyette BNR. DIXDC1 contributes to psychiatric susceptibility by regulating dendritic spine and glutamatergic synapse density via GSK3 and Wnt/betacatenin signaling. Mol Psychiatry. 2018;23(2):467-75.

67. Watcharasit P, Bijur GN, Zmijewski JW, Song L, Zmijewska A, Chen X, Johnson GV, Jope RS. Direct, activating interaction between glycogen synthase kinase-3beta and p53 after DNA damage. Proc Natl Acad Sci U S A. 2002;99(12):7951-5.

68. Wang Z, Ge Y, Bao H, Dworkin L, Peng A, Gong R. Redox-sensitive glycogen synthase kinase 3beta-directed control of mitochondrial permeability transition: rheostatic regulation of acute kidney injury. Free Radic Biol Med. 2013;65:849-58.

69. Yazlovitskaya EM, Edwards E, Thotala D, Fu A, Osusky KL, Whetsell WO Jr, Boone B, Shinohara ET, Hallahan DE. Lithium treatment prevents neurocognitive deficit resulting from cranial irradiation. Cancer Res. 2006; 66(23):11179-86

70. Cross DA, Culbert AA, Chalmers KA, Facci L, Skaper SD, Reith AD. Selective small-molecule inhibitors of glycogen synthase kinase-3 activity protect primary neurones from death. J Neurochem. 2001;77(1):94-102.

71. Thotala DK, Hallahan DE, Yazlovitskaya EM. Glycogen synthase kinase 3beta inhibitors protect hippocampal neurons from radiation-induced apoptosis by regulating MDM2-p53 pathway. Cell Death Differ. 2012;19(3):387-96.

72. Rojo Al, Sagarra MR, Cuadrado A. GSK-3beta down-regulates the transcription factor Nrf2 after oxidant damage: relevance to exposure of neuronal cells to oxidative stress. J Neurochem. 2008;105(1):192-202.

73. Wakatsuki S, Furuno A, Ohshima M, Araki T. Oxidative stress-dependent phosphorylation activates ZNRF1 to induce neuronal/axonal degeneration. J Cell Biol. 2015;211(4):881-96.

74. Tobe BTD, Crain AM, Winquist AM, Calabrese B, Makihara H, Zhao WN, Lalonde J, Nakamura H, Konopaske G, Sidor M, Pernia CD, Yamashita N, Wada M, Inoue Y, Nakamura F, Sheridan SD, Logan RW, Brandel M, Wu D, 
Hunsberger J, Dorsett L, Duerr C, Basa RCB, McCarthy MJ, Udeshi ND, Mertins P, Carr SA, Rouleau GA, Mastrangelo L, Li J, Gutierrez GJ, Brill LM, Venizelos N, Chen G, Nye JS, Manji H, Price JH, McClung CA, Akiskal HS, Alda M, Chuang DM, Coyle JT, Liu Y, Teng YD, Ohshima T, Mikoshiba K, Sidman RL, Halpain S, Haggarty SJ, Goshima Y, Snyder EY. Probing the lithiumresponse pathway in hiPSCs implicates the phosphoregulatory set-point for a cytoskeletal modulator in bipolar pathogenesis. Proc Natl Acad Sci U S A. 2017;114(22):E4462-71.

75. Wakatsuki S, Saitoh F, Araki T. ZNRF1 promotes Wallerian degeneration by degrading AKT to induce GSK3B-dependent CRMP2 phosphorylation. Nat Cell Biol. 2011:13(12):1415-23.

76. Polter A, Beurel E, Yang S, Garner R, Song L, Miller CA, Sweatt JD, McMahon $L$, Bartolucci AA, Li X, Jope RS. Deficiency in the inhibitory serinephosphorylation of glycogen synthase kinase-3 increases sensitivity to mood disturbances. Neuropsychopharmacology. 2010;35(8):1761-74.

77. de Sousa RT, Zanetti MV, Talib LL, Serpa MH, Chaim TM, Carvalho AF, Brunoni AR, Busatto GF, Gattaz WF, Machado-Vieira R. Lithium increases platelet serine-9 phosphorylated GSK-3beta levels in drug-free bipolar disorder during depressive episodes. J Psychiatr Res. 2015;62:78-83.

78. Li X, Liu M, Cai Z, Wang G, Li X. Regulation of glycogen synthase kinase-3 during bipolar mania treatment. Bipolar Disord. 2010;12(7):741-52.

79. Kozlovsky N, Belmaker RH, Agam G. Low GSK-3beta immunoreactivity in postmortem frontal cortex of schizophrenic patients. Am J Psychiatry. 2000; 157(5):831-3.

80. Kozlovsky N, Regenold WT, Levine J, Rapoport A, Belmaker RH, Agam G. GSK-3beta in cerebrospinal fluid of schizophrenia patients. J Neural Transm. 2004;111(8):1093-8.

81. Beasley C, Cotter D, Everall I. An investigation of the Wnt-signalling pathway in the prefrontal cortex in schizophrenia, bipolar disorder and major depressive disorder. Schizophr Res. 2002:58(1):63-7.

82. Ide M, Ohnishi T, Murayama M, Matsumoto I, Yamada K, Iwayama Y, Dedova I, Toyota T, Asada T, Takashima A, Yoshikawa T. Failure to support a genetic contribution of AKT1 polymorphisms and altered AKT signaling in schizophrenia. J Neurochem. 2006;99(1):277-87.

83. Klein PS, Melton DA. A molecular mechanism for the effect of lithium on development. Proc Natl Acad Sci U S A. 1996;93(16):8455-9.

84. Ryves WJ, Harwood AJ. Lithium inhibits glycogen synthase kinase-3 by competition for magnesium. Biochem Biophys Res Commun. 2001;280(3): $720-5$.

85. Beaulieu JM, Sotnikova TD, Yao WD, Kockeritz L, Woodgett JR, Gainetdinov RR, Caron MG. Lithium antagonizes dopamine-dependent behaviors mediated by an AKT/glycogen synthase kinase 3 signaling cascade. Proc Natl Acad Sci U S A. 2004;101(14):5099-104.

86. Dandekar MP, Valvassori SS, Dal-Pont GC, Quevedo J. Glycogen synthase kinase-3beta as a putative therapeutic target for bipolar disorder. Curr Drug Metab. 2018;19(8):663-73.

87. Hur EM, Zhou FQ. GSK3 signalling in neural development. Nat Rev Neurosci. 2010;11(8):539-51.

88. Saraswati AP, Ali Hussaini SM, Krishna NH, Babu BN, Kamal A. Glycogen synthase kinase-3 and its inhibitors: potential target for various therapeutic conditions. Eur J Med Chem. 2018;144:843-58.

89. Shim SS, Stutzmann GE. Inhibition of glycogen synthase Kinase-3: an emerging target in the treatment of traumatic brain injury. J Neurotrauma. 2016;33(23):2065-76.

90. Kozikowski AP, Gaisina IN, Yuan H, Petukhov PA, Blond SY, Fedolak A, Caldarone B, McGonigle P. Structure-based design leads to the identification of lithium mimetics that block mania-like effects in rodents. Possible new GSK-3beta therapies for bipolar disorders. J Am Chem Soc. 2007;129(26): 8328-32.

91. Kalinichev M, Dawson LA. Evidence for antimanic efficacy of glycogen synthase kinase-3 (GSK3) inhibitors in a strain-specific model of acute mania. Int J Neuropsychopharmacol. 2011;14(8):1051-67.

92. Blackwood DH, Fordyce A, Walker MT, St Clair DM, Porteous DJ, Muir WJ. Schizophrenia and affective disorders--cosegregation with a translocation at chromosome 1q42 that directly disrupts brain-expressed genes: clinical and P300 findings in a family. Am J Hum Genet. 2001;69(2):428-33.

93. Millar JK, Christie S, Semple CA, Porteous DJ. Chromosomal location and genomic structure of the human translin-associated factor $X$ gene (TRAX; TSNAX) revealed by intergenic splicing to DISC1, a gene disrupted by a translocation segregating with schizophrenia. Genomics. 2000:67(1):69-77.
94. Millar JK, Wilson-Annan JC, Anderson S, Christie S, Taylor MS, Semple CA, Devon RS, St Clair DM, Muir WJ, Blackwood DH, Porteous DJ. Disruption of two novel genes by a translocation co-segregating with schizophrenia. Hum Mol Genet. 2000;9(9):1415-23.

95. St Clair D, Blackwood D, Muir W, Carothers A, Walker M, Spowart G, Gosden C, Evans HJ. Association within a family of a balanced autosomal translocation with major mental illness. Lancet. 1990;336(8706):13-6.

96. Taylor MS, Devon RS, Millar JK, Porteous DJ. Evolutionary constraints on the disrupted in schizophrenia locus. Genomics. 2003;81(1):67-77.

97. Ma L, Liu Y, Ky B, Shughrue PJ, Austin CP, Morris JA. Cloning and characterization of Disc1, the mouse ortholog of DISC1 (disrupted-inschizophrenia 1). Genomics. 2002;80(6):662-72.

98. Lipska BK, Peters T, Hyde TM, Halim N, Horowitz C, Mitkus S, Weickert CS, Matsumoto M, Sawa A, Straub RE, Vakkalanka R, Herman MM, Weinberger DR, Kleinman JE. Expression of DISC1 binding partners is reduced in schizophrenia and associated with DISC1 SNPs. Hum Mol Genet. 2006;15(8):1245-58.

99. Chen CY, Liu HY, Hsueh YP. TLR3 downregulates expression of schizophrenia gene Disc1 via MYD88 to control neuronal morphology. EMBO Rep. 2017;18(1):169-83.

100. Akbarian S, Kim JJ, Potkin SG, Hetrick WP, Bunney WE Jr, Jones EG. Maldistribution of interstitial neurons in prefrontal white matter of the brains of schizophrenic patients. Arch Gen Psychiatry. 1996;53(5):425-36.

101. Glantz LA, Lewis DA. Decreased dendritic spine density on prefrontal cortical pyramidal neurons in schizophrenia. Arch Gen Psychiatry. 2000;57(1):65-73.

102. Brandon NJ, Handford EJ, Schurov I, Rain JC, Pelling M, Duran-Jimeniz B, Camargo LM, Oliver KR, Beher D, Shearman MS, Whiting PJ. Disrupted in schizophrenia 1 and Nudel form a neurodevelopmentally regulated protein complex: implications for schizophrenia and other major neurological disorders. Mol Cell Neurosci. 2004;25(1):42-55.

103. Bradshaw NJ, Christie S, Soares DC, Carlyle BC, Porteous DJ, Millar JK. NDE1 and NDEL1: multimerisation, alternate splicing and DISC1 interaction. Neurosci Lett. 2009;449(3):228-33.

104. Kamiya A, Tan PL, Kubo K, Engelhard C, Ishizuka K, Kubo A, Tsukita S, Pulver AE, Nakajima K, Cascella NG, Katsanis N, Sawa A. Recruitment of PCM1 to the centrosome by the cooperative action of DISC1 and BBS4: a candidate for psychiatric illnesses. Arch Gen Psychiatry. 2008;65(9):996-1006.

105. Kirkpatrick B, Xu L, Cascella N, Ozeki Y, Sawa A, Roberts RC. DISC1 immunoreactivity at the light and ultrastructural level in the human neocortex. J Comp Neurol. 2006:497(3):436-50.

106. Bradshaw NJ, Soares DC, Carlyle BC, Ogawa F, Davidson-Smith H, Christie S, Mackie S, Thomson PA, Porteous DJ, Millar JK. PKA phosphorylation of NDE1 is DISC1/PDE4 dependent and modulates its interaction with LIS1 and NDEL1. J Neurosci. 2011;31(24):9043-54.

107. Flores R 3rd, Hirota Y, Armstrong B, Sawa A, Tomoda T. DISC1 regulates synaptic vesicle transport via a lithium-sensitive pathway. Neurosci Res. 2011;71(1):71-7.

108. Chenn A, Walsh CA. Regulation of cerebral cortical size by control of cell cycle exit in neural precursors. Science. 2002;297(5580):365-9.

109. Ishizuka K, Kamiya A, Oh EC, Kanki H, Seshadri S, Robinson JF, Murdoch $H$, Dunlop AJ, Kubo K, Furukori K, Huang B, Zeledon M, Hayashi-Takagi A, Okano H, Nakajima K, Houslay MD, Katsanis N, Sawa A. DISC1-dependent switch from progenitor proliferation to migration in the developing cortex. Nature. 2011;473(7345):92-6.

110. Kamiya A, Kubo K, Tomoda T, Takaki M, Youn R, Ozeki Y, Sawamura N, Park U, Kudo C, Okawa M, Ross CA, Hatten ME, Nakajima K, Sawa A. A schizophrenia-associated mutation of DISC1 perturbs cerebral cortex development. Nat Cell Biol. 2005;7(12):1167-78.

111. Ozeki Y, Tomoda T, Kleiderlein J, Kamiya A, Bord L, Fujii K, Okawa M, Yamada N, Hatten ME, Snyder SH, Ross CA, Sawa A. Disrupted-inSchizophrenia-1 (DISC-1): mutant truncation prevents binding to NudE-like (NUDEL) and inhibits neurite outgrowth. Proc Natl Acad Sci U S A. 2003; 100(1):289-94.

112. Deng D, Jian C, Lei L, Zhou Y, McSweeney C, Dong F, Shen Y, Zou D, Wang $Y$, Wu Y, Zhang L, Mao Y. A prenatal interruption of DISC1 function in the brain exhibits a lasting impact on adult behaviors, brain metabolism, and interneuron development. Oncotarget. 2017;8(49):84798-817.

113. Duff BJ, Macritchie KAN, Moorhead TWJ, Lawrie SM, Blackwood DHR. Human brain imaging studies of DISC1 in schizophrenia, bipolar disorder and depression: a systematic review. Schizophr Res. 2013;147(1):1-13. 
114. Eachus H, Bright C, Cunliffe VT, Placzek M, Wood JD, Watt PJ. Disrupted-inSchizophrenia-1 is essential for normal hypothalamic-pituitary-interrenal (HPI) axis function. Hum Mol Genet. 2017;26(11):1992-2005.

115. Hennah W, Tuulio-Henriksson A, Paunio T, Ekelund J, Varilo T, Partonen T, Cannon TD, Lonnqvist J, Peltonen L. A haplotype within the DISC1 gene is associated with visual memory functions in families with a high density of schizophrenia. Mol Psychiatry. 2005;10(12):1097-103.

116. Hikida T, Gamo NJ, Sawa A. DISC1 as a therapeutic target for mental illnesses. Expert Opin Ther Targets. 2012;16(12):1151-60.

117. Hu G, Yang C, Zhao L, Fan Y, Lv Q, Zhao J, Zhu M, Guo X, Bao C, Xu A, Jie Y, Jiang Y, Zhang C, Yu S, Wang Z, Li Z, Yi Z. The interaction of NOS1AP, DISC1, DAOA, and GSK3B confers susceptibility of early-onset schizophrenia in Chinese Han population. Prog Neuro-Psychopharmacol Biol Psychiatry. 2018:81:187-93.

118. Shao L, Lu B, Wen Z, Teng S, Wang L, Zhao Y, Wang L, Ishizuka K, Xu X, Sawa A, Song H, Ming G, Zhong Y. Disrupted-in-Schizophrenia-1 (DISC1) protein disturbs neural function in multiple disease-risk pathways. Hum Mol Genet. 2017;26(14):2634-48.

119. Terrillion CE, Abazyan B, Yang Z, Crawford J, Shevelkin AV, Jouroukhin Y, Yoo KH, Cho CH, Roychaudhuri R, Snyder SH, Jang MH, Pletnikov MV. DISC1 in astrocytes influences adult neurogenesis and Hippocampusdependent behaviors in mice. Neuropsychopharmacology. 2017;42(11): 2242-51.

120. Tomoda T, Hikida T, Sakurai T. Role of DISC1 in neuronal trafficking and its implication in neuropsychiatric manifestation and Neurotherapeutics. Neurotherapeutics. 2017;14(3):623-9.

121. Devon RS, Anderson S, Teague PW, Burgess P, Kipari TM, Semple CA, Millar JK, Muir WJ, Murray V, Pelosi AJ, Blackwood DH, Porteous DJ. Identification of polymorphisms within disrupted in schizophrenia 1 and disrupted in schizophrenia 2, and an investigation of their association with schizophrenia and bipolar affective disorder. Psychiatr Genet. 2001;11(2):71-8.

122. Kockelkorn TT, Arai M, Matsumoto H, Fukuda N, Yamada K, Minabe Y, Toyota T, Ujike H, Sora I, Mori N, Yoshikawa T, Itokawa M. Association study of polymorphisms in the 5 ' upstream region of human DISC1 gene with schizophrenia. Neurosci Lett. 2004;368(1):41-5.

123. Mathieson I, Munafo MR, Flint J. Meta-analysis indicates that common variants at the DISC1 locus are not associated with schizophrenia. Mol Psychiatry. 2012;17(6):634-41.

124. Yang S, Cho YS, Chennathukuzhi VM, Underkoffler LA, Loomes K, Hecht NB. Translin-associated factor $X$ is post-transcriptionally regulated by its partner protein TB-RBP, and both are essential for normal cell proliferation. J Biol Chem. 2004;279(13):12605-14.

125. Finkenstadt PM, Jeon M, Baraban JM. Trax is a component of the Translincontaining RNA binding complex. J Neurochem. 2002;83(1):202-10.

126. Chiaruttini C, Vicario A, Li Z, Baj G, Braiuca P, Wu Y, Lee FS, Gardossi L, Baraban JM, Tongiorgi E. Dendritic trafficking of BDNF mRNA is mediated by translin and blocked by the G196A (Val66Met) mutation. Proc Natl Acad Sci U S A. 2009;106(38):16481-6.

127. Finkenstadt PM, Kang WS, Jeon M, Taira E, Tang W, Baraban JM Somatodendritic localization of Translin, a component of the Translin/Trax RNA binding complex. J Neurochem. 2000;75(4):1754-62.

128. Liu Y, Ye X, Jiang F, Liang C, Chen D, Peng J, Kinch LN, Grishin NV, Liu Q. C3PO, an endoribonuclease that promotes RNAi by facilitating RISC activation. Science. 2009;325(5941):750-3.

129. Asada K, Canestrari E, Fu X, Li Z, Makowski E, Wu YC, Mito JK, Kirsch DG, Baraban J, Paroo Z. Rescuing dicer defects via inhibition of an anti-dicing nuclease. Cell Rep. 2014;9(4):1471-81.

130. Park AJ, Havekes R, Fu X, Hansen R, Tudor JC, Peixoto L, Li Z, Wu YC, Poplawski SG, Baraban JM, Abel T. Learning induces the translin/trax RNase complex to express activin receptors for persistent memory. Elife. 2017;6.

131. Geaghan M, Cairns MJ. MicroRNA and posttranscriptional dysregulation in psychiatry. Biol Psychiatry. 2015;78(4):231-9.

132. Sun CN, Cheng HC, Chou JL, Lee SY, Lin YW, Lai HL, Chen HM, Chern Y. Rescue of p53 blockage by the $A(2 A)$ adenosine receptor via a novel interacting protein, translin-associated protein X. Mol Pharmacol. 2006;70(2):454-66.

133. Fredholm BB, Chern Y, Franco R, Sitkovsky M. Aspects of the general biology of adenosine A2A signaling. Prog Neurobiol. 2007;83(5):263-76.

134. Sun CN, Chuang HC, Wang JY, Chen SY, Cheng YY, Lee CF, Chern Y. The A2A adenosine receptor rescues neuritogenesis impaired by p53 blockage via KIF2A, a kinesin family member. Dev Neurobiol. 2010;70(8):604-21.
135. Li C, Zheng Y, Qin W, Tao R, Pan Y, XU Y, Li X, Gu N, Feng G, He L. A familybased association study of kinesin heavy chain member 2 gene (KIF2) and schizophrenia. Neurosci Lett. 2006;407(2):151-5.

136. Erdemir T, Bilican B, Oncel D, Goding CR, Yavuzer U. DNA damagedependent interaction of the nuclear matrix protein C1D with Translinassociated factor X (TRAX). J Cell Sci. 2002;115(Pt 1):207-16.

137. Wang JY, Chen SY, Sun CN, Chien T, Chern Y. A central role of TRAX in the ATM-mediated DNA repair. Oncogene. 2016;35(13):1657-70.

138. Tsuang MT, Nossova N, Yager T, Tsuang MM, Guo SC, Shyu KG, Glatt SJ, Liew CC. Assessing the validity of blood-based gene expression profiles for the classification of schizophrenia and bipolar disorder: a preliminary report. Am J Med Genet B Neuropsychiatr Genet. 2005;133B(1):1-5.

139. Zhang F, Xu Y, Liu P, Fan H, Huang X, Sun G, Song Y, Sham PC. Association analyses of the interaction between the ADSS and ATM genes with schizophrenia in a Chinese population. BMC Med Genet. 2008;9:119.

140. Cannon TD, Hennah W, van Erp TG, Thompson PM, Lonnqvist J, Huttunen M, Gasperoni T, Tuulio-Henriksson A, Pirkola T, Toga AW, Kaprio J, Mazziotta J, Peltonen L. Association of DISC1/TRAX haplotypes with schizophrenia, reduced prefrontal gray matter, and impaired short- and long-term memory. Arch Gen Psychiatry. 2005;62(11):1205-13.

141. Chiu FL, Lin JT, Chuang CY, Chien T, Chen CM, Chen KH, Hsiao HY, Lin YS, Chern Y, Kuo HC. Elucidating the role of the A2A adenosine receptor in neurodegeneration using neurons derived from Huntington's disease iPSCs. Hum Mol Genet. 2015;24(21):6066-79.

142. Hwang Y, Kim J, Shin JY, Kim JI, Seo JS, Webster MJ, Lee D, Kim S. Gene expression profiling by mRNA sequencing reveals increased expression of immune/inflammation-related genes in the hippocampus of individuals with schizophrenia. Transl Psychiatry. 2013;3:e321.

143. Villar-Menendez I, Diaz-Sanchez S, Blanch M, Albasanz JL, Pereira-Veiga T, Monje A, Planchat LM, Ferrer I, Martin M, Barrachina M. Reduced striatal adenosine A2A receptor levels define a molecular subgroup in schizophrenia. J Psychiatr Res. 2014;51:49-59.

144. Ferre S, O'Connor WT, Snaprud P, Ungerstedt U, Fuxe K. Antagonistic interaction between adenosine A2A receptors and dopamine D2 receptors in the ventral striopallidal system. Implications for the treatment of schizophrenia. Neuroscience. 1994;63(3):765-73.

145. Wardas J. Potential role of adenosine A2A receptors in the treatment of schizophrenia. Front Biosci. 2008;13:4071-96.

146. Su P, Li S, Chen S, Lipina TV, Wang M, Lai TK, Lee FH, Zhang H, Zhai D, Ferguson SS, Nobrega JN, Wong AH, Roder JC, Fletcher PJ, Liu F. A dopamine D2 receptor-DISC1 protein complex may contribute to antipsychotic-like effects. Neuron. 2014;84(6):1302-16.

147. Boison D. Adenosine as a neuromodulator in neurological diseases. Curr Opin Pharmacol. 2008;8(1):2-7.

148. Lara DR. Inhibitory deficit in schizophrenia is not necessarily a GABAergic deficit. Cell Mol Neurobiol. 2002;22(3):239-47.

149. Lara DR, Dall'Igna OP, Ghisolfi ES, Brunstein MG. Involvement of adenosine in the neurobiology of schizophrenia and its therapeutic implications. Prog Neuro-Psychopharmacol Biol Psychiatry. 2006;30(4):617-29.

150. Lara DR, Souza DO. Schizophrenia: a purinergic hypothesis. Med Hypotheses. 2000;54(2):157-66.

151. Shen HY, Singer P, Lytle N, Wei CJ, Lan JQ, Williams-Karnesky RL, Chen JF, Yee BK, Boison D. Adenosine augmentation ameliorates psychotic and cognitive endophenotypes of schizophrenia. J Clin Invest. 2012;122(7):2567-77.

152. Yee BK, Singer P, Chen JF, Feldon J, Boison D. Transgenic overexpression of adenosine kinase in brain leads to multiple learning impairments and altered sensitivity to psychomimetic drugs. Eur J Neurosci. 2007;26(11):3237-52.

153. Akhondzadeh S, Shasavand E, Jamilian H, Shabestari O, Kamalipour A. Dipyridamole in the treatment of schizophrenia: adenosine-dopamine receptor interactions. J Clin Pharm Ther. 2000;25(2):131-7.

154. Boison D, Singer $P$, Shen HY, Feldon J, Yee BK. Adenosine hypothesis of schizophrenia--opportunities for pharmacotherapy. Neuropharmacology. 2012;62(3):1527-43.

155. Hirota T, Kishi T. Adenosine hypothesis in schizophrenia and bipolar disorder: a systematic review and meta-analysis of randomized controlled trial of adjuvant purinergic modulators. Schizophr Res. 2013;149(1-3):88-95.

156. Chuang DM, Wang Z, Chiu CT. GSK-3 as a target for Lithium-induced neuroprotection against excitotoxicity in neuronal cultures and animal models of ischemic stroke. Front Mol Neurosci. 2011;4:15.

157. Freland L, Beaulieu JM. Inhibition of GSK3 by lithium, from single molecules to signaling networks. Front Mol Neurosci. 2012;5:14. 
158. Shao L, Young LT, Wang JF. Chronic treatment with mood stabilizers lithium and valproate prevents excitotoxicity by inhibiting oxidative stress in rat cerebral cortical cells. Biol Psychiatry. 2005;58(11):879-84.

159. Chen G, Zeng WZ, Yuan PX, Huang LD, Jiang YM, Zhao ZH, Manji HK. The mood-stabilizing agents lithium and valproate robustly increase the levels of the neuroprotective protein bcl-2 in the CNS. J Neurochem. 1999;72(2):879-82.

160. Chen RW, Chuang DM. Long term lithium treatment suppresses p53 and Bax expression but increases $\mathrm{BCl}-2$ expression. A prominent role in neuroprotection against excitotoxicity. J Biol Chem. 1999;274(10):6039-42.

161. Yang ES, Wang $H$, Jiang $G$, Nowsheen S, Fu A, Hallahan DE, Xia F. Lithiummediated protection of hippocampal cells involves enhancement of DNAPK-dependent repair in mice. J Clin Invest. 2009;119(5):1124-35.

162. Chuang DM. Neuroprotective and neurotrophic actions of the mood stabilizer lithium: can it be used to treat neurodegenerative diseases? Crit Rev Neurobiol. 2004;16(1-2):83-90.

163. Maqbool M, Mobashir M, Hoda N. Pivotal role of glycogen synthase kinase-3: a therapeutic target for Alzheimer's disease. Eur J Med Chem. 2016;107:63-81.

164. de Lera Ruiz M, Lim YH, Zheng J. Adenosine A2A receptor as a drug discovery target. J Med Chem. 2014;57(9):3623-50.

165. Jones KR, Choi U, Gao JL, Thompson RD, Rodman LE, Malech HL, Kang EM. A novel method for screening adenosine receptor specific agonists for use in adenosine drug development. Sci Rep. 2017;7:44816.

166. Liu Y, Zou H, Zhao P, Sun B, Wang J, Kong Q, Mu L, Zhao S, Wang G, Wang D, Zhang Y, Zhao J, Yin P, Liu L, Zhao X, Li H. Activation of the adenosine $\mathrm{A} 2 \mathrm{~A}$ receptor attenuates experimental autoimmune encephalomyelitis and is associated with increased intracellular calcium levels. Neuroscience. 2016; 330:150-61.

167. Howe AS, Buttenschon HN, Bani-Fatemi A, Maron E, Otowa T, Erhardt A, Binder EB, Gregersen NO, Mors O, Woldbye DP, Domschke K, Reif A, Shlik J, Koks S, Kawamura Y, Miyashita A, Kuwano R, Tokunaga K, Tanii H, Smoller JW, Sasaki T, Koszycki D, De Luca V. Candidate genes in panic disorder: meta-analyses of 23 common variants in major anxiogenic pathways. Mol Psychiatry. 2016;21(5):665-79.

168. Bray JD, Chennathukuzhi VM, Hecht NB. Identification and characterization of CDNAs encoding four novel proteins that interact with translin associated factor-X. Genomics. 2002;79(6):799-808.

169. Sanderson JL, Dell'Acqua ML. AKAP signaling complexes in regulation of excitatory synaptic plasticity. Neuroscientist. 2011;17(3):321-36.

170. Suarez-Rama JJ, Arrojo M, Sobrino B, Amigo J, Brenlla J, Agra S, Paz E, Brion M, Carracedo A, Paramo M, Costas J. Resequencing and association analysis of coding regions at twenty candidate genes suggest a role for rare risk variation at AKAP9 and protective variation at NRXN1 in schizophrenia susceptibility. J Psychiatr Res. 2015;66-67:38-44.

171. Cheng EP, Yuan C, Navedo MF, Dixon RE, Nieves-Cintron M, Scott JD, Santana LF. Restoration of normal L-type Ca2+ channel function during Timothy syndrome by ablation of an anchoring protein. Circ Res. 2011;109(3):255-61.

172. Nuytens K, Tuand K, Di Michele M, Boonen K, Waelkens E, Freson K, Creemers JW. Platelets of mice heterozygous for neurobeachin, a candidate gene for autism spectrum disorder, display protein changes related to aberrant protein kinase A activity. Mol Autism. 2013;4(1):43.

173. Pryde KR, Smith HL, Chau KY, Schapira AH. PINK1 disables the anti-fission machinery to segregate damaged mitochondria for mitophagy. J Cell Biol. 2016;213(2):163-71.

174. McGuire JL, Depasquale EA, Funk AJ, O'Donnovan SM, Hasselfeld K, Marwaha S, Hammond JH, Hartounian V, Meador-Woodruff JH, Meller J, McCullumsmith RE. Abnormalities of signal transduction networks in chronic schizophrenia. NPJ Schizophr. 2017;3(1):30.

175. Schilders G, Egberts WV, Raijmakers R, Pruijn GJ. C1D is a major autoantibody target in patients with the polymyositis-scleroderma overlap syndrome. Arthritis Rheum. 2007;56(7):2449-54.

176. Kilpinen H, Ylisaukko-Oja T, Hennah W, Palo OM, Varilo T, Vanhala R, Nieminen-von WT, von Wendt L, Paunio T, Peltonen L. Association of DISC1 with autism and Asperger syndrome. Mol Psychiatry. 2008;13(2):187-96.

177. Zheng F, Wang L, Jia M, Yue W, Ruan Y, Lu T, Liu J, Li J, Zhang D. Evidence for association between disrupted-in-schizophrenia 1 (DISC1) gene polymorphisms and autism in Chinese Han population: a family-based association study. Behav Brain Funct. 2011;7:14.

178. Sawa A, Ishizuka K, Katsanis N. The potential of DISC1 protein as a therapeutic target for mental illness. Expert Opin Ther Targets. 2016;20(6):641-3.
179. Bae SM, Hong JY. The Wnt signaling pathway and related therapeutic drugs in autism Spectrum disorder. Clin Psychopharmacol Neurosci. 2018;16(2):129-35.

180. Wu HF, Chen PS, Chen YJ, Lee CW, Chen IT, Lin HC. Alleviation of N-methylD-aspartate receptor-dependent long-term depression via regulation of the glycogen synthase kinase-3beta pathway in the amygdala of a Valproic acid-induced animal model of autism. Mol Neurobiol. 2017;54(7):5264-76.

181. DeVeaugh-Geiss AM, West SL, Miller WC, Sleath B, Kroenke K, Gaynes BN. Depression and comorbid panic in primary care patients. J Affect Disord. 2010;123(1-3):283-90.

182. Nguyen T, Fan T, George SR, Perreault ML. Disparate effects of Lithium and a GSK-3 inhibitor on neuronal oscillatory activity in prefrontal cortex and Hippocampus. Front Aging Neurosci. 2017:9:434.

183. Bray JD, Chennathukuzhi VM, Hecht NB. KIF2Abeta: a kinesin family member enriched in mouse male germ cells, interacts with translin associated factorX (TRAX). Mol Reprod Dev. 2004;69(4):387-96.

184. Garwain O, Scarlata S. Phospholipase Cbeta-TRAX association is required for PC12 cell differentiation. J Biol Chem. 2016;291(44):22970-6.

185. Scarlata S, Garwain O, Williams L, Burguera IG, Rosati B, Sahu S, Guo Y, Philip F, Golebiewska U. Phospholipase Cbeta connects $G$ protein signaling with RNA interference. Adv Biol Regul. 2016;61:51-7.

186. Lo Vasco VR, Cardinale G, Polonia P. Deletion of PLCB1 gene in schizophrenia-affected patients. J Cell Mol Med. 2012;16(4):844-51.

187. Udawela M, Scarr E, Hannan AJ, Thomas EA, Dean B. Phospholipase C beta 1 expression in the dorsolateral prefrontal cortex from patients with schizophrenia at different stages of illness. Aust N Z J Psychiatry. 2011;45(2):140-7.

188. Carrascosa-Romero MC, Suela J, Alfaro-Ponce B, Cepillo-Boluda AJ. Xchromosome-linked ichthyosis associated to epilepsy, hyperactivity, autism and mental retardation, due to the Xp22.31 microdeletion. Rev Neurol. 2012:54(4):241-8.

189. Gomez-Escobar N, Almobadel N, Alzahrani O, Feichtinger J, Planells-Palop V, Alshehri Z, Thallinger GG, Wakeman JA, McFarlane RJ. Translin and Trax differentially regulate telomere-associated transcript homeostasis. Oncotarget. 2016;7(23):33809-20.

190. Kobayashi S, Takashima A, Anzai K. The dendritic translocation of translin protein in the form of BC1 RNA protein particles in developing rat hippocampal neurons in primary culture. Biochem Biophys Res Commun. 1998:253(2):448-53.

191. Arias B, Fabbri C, Serretti A, Drago A, Mitjans M, Gasto C, Catalan R, Fananas L. DISC1-TSNAX and DAOA genes in major depression and citalopram efficacy. J Affect Disord. 2014;168:91-7.

192. Li N, Zheng J, Li H, Deng J, Hu M, Wu H, Li W, Li F, Lan X, Lu J, Zhou Y. Identification of chimeric TSNAX-DISC1 resulting from intergenic splicing in endometrial carcinoma through high-throughput RNA sequencing. Carcinogenesis. 2014;35(12):2687-97.

193. Stein JM, Bergman W, Fang Y, Davison L, Brensinger C, Robinson MB, Hecht NB, Abel T. Behavioral and neurochemical alterations in mice lacking the RNA-binding protein translin. J Neurosci. 2006;26(8):2184-96.

194. Teng S, Thomson PA, McCarthy S, Kramer M, Muller S, Lihm J, Morris S, Soares DC, Hennah W, Harris S, Camargo LM, Malkov V, McIntosh AM, Millar JK, Blackwood DH, Evans KL, Deary IJ, Porteous DJ, McCombie WR. Rare disruptive variants in the DISC1 Interactome and Regulome: association with cognitive ability and schizophrenia. Mol Psychiatry. 2018;23(5):1270-7.

195. Costas J, Suarez-Rama JJ, Carrera N, Paz E, Paramo M, Agra S, Brenlla J, Ramos-Rios R, Arrojo M. Role of DISC1 interacting proteins in schizophrenia risk from genome-wide analysis of missense SNPs. Ann Hum Genet. 2013;77(6):504-12

196. Sawamura N, Ando T, Maruyama Y, Fujimuro M, Mochizuki H, Honjo K, Shimoda M, Toda H, Sawamura-Yamamoto T, Makuch LA, Hayashi A, Ishizuka K, Cascella NG, Kamiya A, Ishida N, Tomoda T, Hai T, FurukuboTokunaga K, Sawa A. Nuclear DISC1 regulates CRE-mediated gene transcription and sleep homeostasis in the fruit fly. Mol Psychiatry. 2008; 13(12):1138-48.

197. Soda T, Frank C, Ishizuka K, Baccarella A, Park YU, Flood Z, Park SK, Sawa A, Tsai LH. DISC1-ATF4 transcriptional repression complex: dual regulation of the CAMP-PDE4 cascade by DISC1. Mol Psychiatry. 2013; 18(8):898-908.

198. Hennah W, Thomson P, McQuillin A, Bass N, Loukola A, Anjorin A, Blackwood D, Curtis D, Deary IJ, Harris SE, Isometsa ET, Lawrence J, Lonnqvist J, Muir W, Palotie A, Partonen T, Paunio T, Pylkko E, Robinson M, Soronen P, Suominen K, Suvisaari J, Thirumalai S, St Clair D, Gurling 
H, Peltonen L, Porteous D. DISC1 association, heterogeneity and interplay in schizophrenia and bipolar disorder. Mol Psychiatry. 2009; 14(9):865-73.

199. Madarampalli B, Yuan Y, Liu D, Lengel K, Xu Y, Li G, Yang J, Liu X, Lu Z, Liu DX. ATF5 connects the Pericentriolar materials to the proximal end of the mother centriole. Cell. 2015;162(3):580-92.

200. Morris JA, Kandpal G, Ma L, Austin CP. DISC1 (disrupted-in-schizophrenia 1) is a centrosome-associated protein that interacts with MAP1A, MIPT3, ATF4/ 5 and NUDEL: regulation and loss of interaction with mutation. Hum Mol Genet. 2003;12(13):1591-608.

201. Murdoch H, Mackie S, Collins DM, Hill EV, Bolger GB, Klussmann E, Porteous DJ, Millar JK, Houslay MD. Isoform-selective susceptibility of DISC1/ phosphodiesterase-4 complexes to dissociation by elevated intracellular cAMP levels. J Neurosci. 2007;27(35):9513-24.

202. Tomppo L, Hennah W, Lahermo P, Loukola A, Tuulio-Henriksson A, Suvisaari J, Partonen T, Ekelund J, Lonnqvist J, Peltonen L. Association between genes of disrupted in schizophrenia 1 (DISC1) interactors and schizophrenia supports the role of the DISC1 pathway in the etiology of major mental illnesses. Biol Psychiatry. 2009;65(12):1055-62.

203. De Rienzo G, Bishop JA, Mao Y, Pan L, Ma TP, Moens CB, Tsai LH, Sive H. Disc1 regulates both beta-catenin-mediated and noncanonical Wnt signaling during vertebrate embryogenesis. FASEB J. 2011;25(12):4184-97.

204. Singh KK, Ge X, Mao Y, Drane L, Meletis K, Samuels BA, Tsai LH. Dixdc1 is a critical regulator of DISC1 and embryonic cortical development. Neuron. 2010;67(1):33-48.

205. Bradshaw NJ, Porteous DJ. DISC1-binding proteins in neural development, signalling and schizophrenia. Neuropharmacology. 2012;62(3):1230-41.

206. Wang Q, Charych El, Pulito VL, Lee JB, Graziane NM, Crozier RA, RevillaSanchez R, Kelly MP, Dunlop AJ, Murdoch H, Taylor N, Xie Y, Pausch M, Hayashi-Takagi A, Ishizuka K, Seshadri S, Bates B, Kariya K, Sawa A, Weinberg RJ, Moss SJ, Houslay MD, Yan Z, Brandon NJ. The psychiatric disease risk factors DISC1 and TNIK interact to regulate synapse composition and function. Mol Psychiatry. 2011;16(10):1006-23.

207. Mead CL, Kuzyk MA, Moradian A, Wilson GM, Holt RA, Morin GB. Cytosolic protein interactions of the schizophrenia susceptibility gene dysbindin. J Neurochem. 2010;113(6):1491-503.

208. Ikuta J, Maturana A, Fujita T, Okajima T, Tatematsu K, Tanizawa K, Kuroda S. Fasciculation and elongation protein zeta-1 (FEZ1) participates in the polarization of hippocampal neuron by controlling the mitochondrial motility. Biochem Biophys Res Commun. 2007;353(1):127-32.

209. Miyoshi K, Honda A, Baba K, Taniguchi M, Oono K, Fujita T, Kuroda S, Katayama T, Tohyama M. Disrupted-in-schizophrenia 1, a candidate gene for schizophrenia, participates in neurite outgrowth. Mol Psychiatry. 2003; 8(7):685-94.

210. Wang $X$, Schwarz TL. The mechanism of $\mathrm{Ca} 2+-$ dependent regulation of kinesin-mediated mitochondrial motility. Cell. 2009;136(1):163-74.

211. Wu YC, Williamson R, Li Z, Vicario A, Xu J, Kasai M, Chern Y, Tongiorgi E, Baraban JM. Dendritic trafficking of brain-derived neurotrophic factor mRNA: regulation by translin-dependent and -independent mechanisms. J Neurochem. 2011:116(6):1112-21.

212. Birkenbihl RP, Subramani S. Cloning and characterization of rad21 an essential gene of Schizosaccharomyces pombe involved in DNA doublestrand-break repair. Nucleic Acids Res. 1992;20(24):6605-11.

213. Xu H, Balakrishnan K, Malaterre J, Beasley M, Yan Y, Essers J, Appeldoorn E, Tomaszewski JM, Vazquez M, Verschoor S, Lavin MF, Bertoncello I, Ramsay RG, McKay MJ. Rad21-cohesin haploinsufficiency impedes DNA repair and enhances gastrointestinal radiosensitivity in mice. PLoS One. 2010;5(8):e12112.

Ready to submit your research? Choose BMC and benefit from:
- fast, convenient online submission
- thorough peer review by experienced researchers in your field
- rapid publication on acceptance
- support for research data, including large and complex data types
- gold Open Access which fosters wider collaboration and increased citations
- maximum visibility for your research: over 100M website views per year
At BMC, research is always in progress.
Learn more biomedcentral.com/submissions

